\title{
Update on treatment and preventive interventions against COVID-19: an overview of potential pharmacological agents and vaccines
}

Yinan Xiao ${ }^{1,2 \dagger}$, Hanyue Xu ${ }^{2,3 \dagger}$, Wen Guo ${ }^{2,3 \dagger}$, Yunuo Zhao ${ }^{1,3}$, Yuling Luo ${ }^{1,3}$, Ming Wang ${ }^{4}$, Zhiyao He ${ }^{5}$, Zhenyu Ding ${ }^{1,3}$, Jiyan Liu', ${ }^{1,3}$, Lei Deng ${ }^{6}$, Fushen Sha ${ }^{7}$ and Xuelei Ma $a^{1,3^{*}}$

\begin{abstract}
The outbreak of coronavirus disease 2019 (COVID-19) triggered by the new member of the coronaviridae family, severe acute respiratory syndrome coronavirus 2 (SARS-CoV-2), has created an unprecedented challenge for global health. In addition to mild to moderate clinical manifestations such as fever, cough, and fatigue, severe cases often developed lethal complications including acute respiratory distress syndrome (ARDS) and acute lung injury. Given the alarming rate of infection and increasing trend of mortality, the development of underlying therapeutic and preventive treatment, as well as the verification of its effectiveness, are the top priorities. Current research mainly referred to and evaluated the application of the empirical treatment based on two precedents, severe acute respiratory syndrome (SARS) and Middle East respiratory syndrome (MERS), including antiviral drugs targeting different stages of virus replication, immunotherapy modulating the overactivated inflammation response, and other therapies such as herbal medicine and mesenchymal stem cells. Besides, the ongoing development of inventing prophylactic interventions such as various vaccines by companies and institutions worldwide is crucial to decline morbidity and mortality. This review mainly focused on promising candidates for the treatment of COVID-19 and collected recently updated evidence relevant to its feasibility in clinical practice in the near future.
\end{abstract}

Keywords: SARS-CoV-2, COVID-19, Antiviral drugs, Immunotherapy, Vaccines

\section{Introduction}

Coronavirus disease 2019 (COVID-19) is a severe acute respiratory syndrome that has infected more than 23 , 300,000 patients and caused 806,410 deaths from 216 countries and territories so far. The pathogen of COVID-19 is severe acute respiratory syndrome coronavirus 2 (SARS-CoV-2), a new member of the coronaviridae family that also includes severe acute respiratory syndrome coronavirus (SARS-CoV) and Middle East

\footnotetext{
*Correspondence: drmaxuelei@gmail.com

${ }^{\dagger}$ Yinan Xiao, Hanyue Xu and Wen Guo contributed equally to this work.

'Department of Biotherapy, State Key Laboratory of Biotherapy, West China Hospital, Sichuan University, Chengdu 610041, China

${ }^{3}$ West China Hospital, Sichuan University, Chengdu 610041, China Full list of author information is available at the end of the article
}

respiratory syndrome coronavirus (MERS-CoV) [1-3]. Bats, the natural reservoirs of SARS-CoV and MERS$\mathrm{CoV}$, might also be the source of COVID-19 due to the similarity of RaTG13 from the short RNA-dependent RNA polymerase (RdRp) region between bat coronavirus and SARS-CoV-2 $[1,4,5]$. The main mode of transmission is airborne, contact transmission and respiratory droplets and the median incubation period from exposure to onset for COVID-19 was about 3.0 days [6].

The majority of confirmed cases are between 30 and 79 years of age and that patients older than 60 tend to develop more serious symptoms or even die [7, 8]. Approximately $25.2-50.5 \%$ of patients with SARS-CoV-2 infection have one or more underlying diseases, 
including hypertension, diabetes, chronic obstructive pulmonary disease, cardiovascular disease, and malignancy $[9,10]$. The clinical manifestations of patients with SARS-CoV-2 infection range from mild nonspecific symptoms to severe pneumonia with organ function damage. The main clinical symptoms of COVID-19 are fever (83-98\%), cough (59-82\%), shortness of breath (19-55\%), weakness (38.1-69.6\%), sputum production (28.2-56.5\%), headache $(6.5-33.9 \%)$ and muscle aches (11-44\%), which are similar to severe acute respiratory syndrome (SARS) and Middle East respiratory syndrome (MERS) [11].

For COVID-19, chest computed tomography (CT) plays a very important role in detecting infected individuals, with imaging showing mainly ground-glass opacity, interstitial abnormalities, patchy shadowing, crazypaving pattern and septal thickening [12-14]. Therefore, the CT images of COVID-19 change in a variety of forms rapidly [15]. Besides, the changing levels of Creactive protein (CRP), erythrocyte sedimentation rate, serum ferritin and interleukin-6 (IL-6), d-dimer, lactate dehydrogenase and creatine kinase might also indicate the disease progression [16].

Confirmation of SARS-CoV-2 infection mainly relies on the positive results of high-throughput sequencing or real-time reverse transcriptase-polymerase chain reaction (RT-PCR) test results [17]. Additionally, chest CT with its high sensitivity to COVID-19, has been given more value in the diagnosis [18].

The current treatment of COVID-19 depends on existing antiviral drugs and immunotherapy [19]. The mechanism of antiviral drugs is targeting various stages of the viral invasion pathway including virus recognition, fusion, entry and genome proliferation. Currently the main targets are the angiotensin-converting enzyme 2 (ACE2) receptor and the transmembrane protease/ serine subfamily member 2 (TMPRSS2) and common types of drugs are protease inhibitors, RNA polymerase inhibitors and interferons [20]. SARS-CoV-2 induces a hyperinflammatory state characterized by an excessive immune response and cytokine dysregulation, which eventually leads to cytokine storms and fatal complications [21]. Thus, in addition to antiviral drugs and symptomatic treatment, immunomodulatory therapy is another critical measure. Common treatment options include corticosteroids, anti-cytokine drugs, Janus kinase (JAK) inhibitors, chloroquine (CQ), hydroxychloroquine (HCQ), convalescent plasma, Intravenous immunoglobulin (IVIG) and interferon (IFN). In addition to these two broad categories of treatment options, stem cell therapy and traditional herbal treatments could also be promising medication [22, 23]. For the prevention of COVID-19, a large number of vaccines are already in the development process, mainly including mRNA vaccine, DNA vaccine, recombinant vaccine $\mathrm{Ad} 5-\mathrm{nCoV}$ $[24,25]$.

In this review we collected updated evidence regarding the usage of various therapies for COVID-19 in clinical practice and its feasibility, hoping to offer helpful instructions for clinical management and strategies.

\section{Introduction of SARS-CoV-2}

SARS-CoV-2 is tightly associated with SARS-CoV, both originating from bat [26-29]. For SARS-CoV, the intermediate hosts for zoonotic transmission of SARS-CoV between bats and humans are palm civets and raccoon dogs, while for SARS-CoV-2, the intermediate hosts have not been identified yet $[30,31]$. Many pathogenic zoonotic pathogens belong to the b-coronavirus genus, including viruses with high pathogenic rate: SARS-CoV, MERS-CoV, and SARS-CoV-2 and four lowpathogenicity coronaviruses: $\mathrm{HCoV}-\mathrm{OC} 43, \mathrm{HCoV}-$ HKU1, HCoV-NL63, and HCoV-229E [32]. Coronaviruses get their name because their outer membrane looks like a crown under an electron microscope. The main pathogenesis of SARS-COV is the direct infection of macrophages and $\mathrm{T}$ cells, and SARS-COV-2 may also be pathogenic through infection of immune cells [33]. The mechanisms of SARS-COV-2 injury have been proposed, including: (1) infecting target cells expressing ACE-2, such as immune cells; (2) inhibiting IFN response and promoting virus replication; (3) increasing the activation of neutrophils and macrophages and the release of proinflammatory cytokines, leading lung injury; and (4) activating specific Th1/Th17 and B cells, leading to a series of inflammatory responses associated with SARS-CoV-2 antibodies [34]. The structure of SARS-CoV-2 and its reproduction in the host cells are described as follows (Fig. 1).

\section{Membrane fusion and virus invasion}

Spike (S) glycoprotein, a $150 \mathrm{kDa}$ highly $\mathrm{N}$-glycosylated protein, protrudes on the viral surface as homotrimers and plays a crucial in the entry of coronavirus into host cells [35]. S protein is composed of two functional subunits: S1 subunit contains N-terminal domain (NTD) and C-terminal domain (CTD), and S2 subunit is transmembrane and has a short cytoplasmic domain. Before fusion, S1 and S2 are noncovalently bound in many CoVs [36-43]. The primary function of S1 subunit is to bind to host cell receptors, while the main function of S2 subunit is to mediate the fusion of virus and cellular membrane. In addition to receptor-binding, S1 subunit also plays a role in stabilizing the prefusion state of membrane-anchored S2 subunit [39, 43-46]. During the process of membrane fusion between virus and susceptible cells, $\mathrm{S}$ protein needs to be activated by $\mathrm{S} 2$ ' site, which is located upstream of fusion peptide and forms 


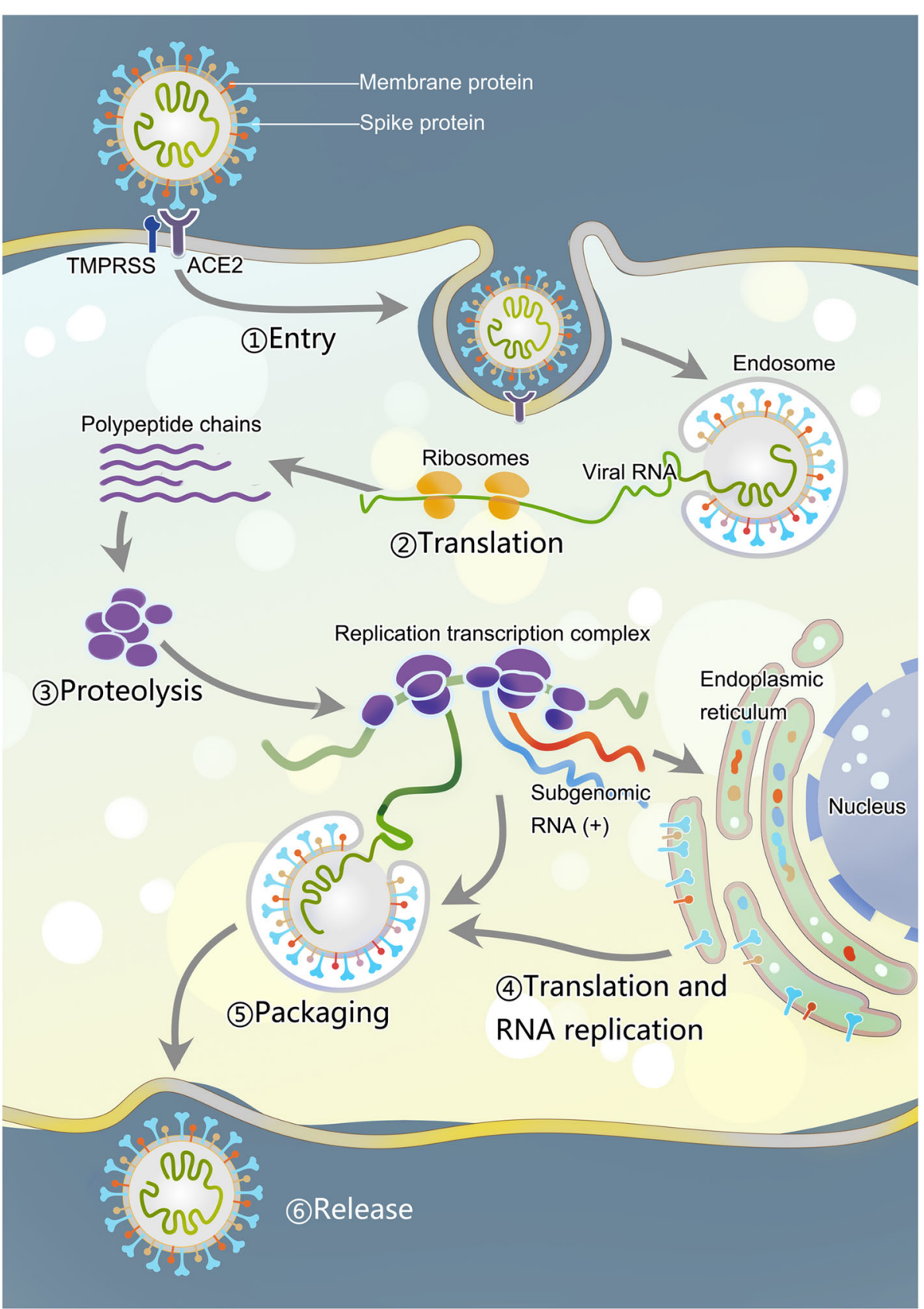

Fig. 1 The membrane fusion, replication, packaging and release of SARS-Cov-2. SARS-CoV-2 has four structural proteins, including spike (S), membrane (M), envelope (E), nucleocapsid (N) proteins. (T) The entry of coronavirus into host cells is mediated by the $S$ glycoprotein, which can be activated by transmembrane protease/ serine subfamily member 2 (TMPRSS2). (2)After the entry of coronaviral genome, viral genomic RNA will start to replicate and synthesize polypeptide chains. (3These polypeptide chains later forms proteolysis which constitutes replication transcription complex to assist the synthesis of other viral structural proteins (4)Following the synthesis of genomic and sub-genomic RNA replication, the S, E, and $\mathrm{M}$ proteins are translated and then they are sequentially transported along the secretory pathway into the endoplasmic reticulum (5Then the proteins are modified and packaged in the endoplasmic reticulum-Golgi intermediate compartment. (6Inside the compartment, the viral genome enveloped by the $\mathrm{N}$ protein will bud into the membrane, thus forming and releasing a mature virus

irreversible conformational changes through the host proteases [36, 41, 42, 47, 48]. Then, a fusion peptide will be inserted into the host cell membrane, and two heptad repeats in S2 will join together to form an antiparallel six-helix bundle [37]. Thus, the entry of coronavirus into susceptible cells involves two main processes, proteolytic activation and receptor binding. Each kind of coronavirus has a specific S1 subunit and a corresponding 
invasion receptor. For example, the structure involved in the surface recognition of MERs-CoV S is domain A, which can recognize the non-acetylated sialoside attached receptor and facilitate the binding of domain $B$ (SB) and the entrance receptor dipeptidyl peptidase 4 [49-53]. For SARS-CoV and several SARS-related coronaviruses, the entry of the virus into the target cell is mediated by SB binding to the receptor of ACE2 [26, 46, 54, 55].

The $\mathrm{S}$ trimer is decorated with $\mathrm{N}$-linked glycan, which guarantees proper folding, modulates the interaction with host proteases and neutralizes Abs [56-58]. Due to $\mathrm{S}$ trimer exists on the surface of virus and can mediate virus invasion, it is an important target for drug design. Previous studies used human-neutralizing Abs from patients infected with SARS-CoV [59] or MERS-CoV [60] and $\mathrm{S}$ from SARS-CoV and MERS-CoV to explore the mechanisms by which $\mathrm{SB}$ attaches to host receptors [57]. Human ACE2 (hACE2) is a receptor, which highly expresses on intestinal cells and lung cells. It has a comparable affinity to SARS-CoV SB and SARS-CoV-2 SB, which both use the $\mathrm{C}$-terminal domain to interact with hACE2 [61]. The structure of SARS-COV-2-CTD is similar to that of SARS-COV, and the sequence consistency is up to $73.9 \%$. There are many similar binding sites between SARS-COV-2 and SARS-COV in their binding to hACE2, indicating that $\mathrm{CoV}$ has evolved to bind to hACE2 in the "hotspot" region [61]. However, SARS-COV-2 $\mathrm{S}$ protein binds to hACE2 more closely than SARS-COV with more chemical bonds and a larger buried surface area $[61,62]$.

\section{Replication, assembly and release}

After the entry of the coronaviral genome, the viral genomic RNA begins to replicate. The replication of viral RNA depends on the materials of the host cells. During the process of replication, the RNA polymerase interacts with the lead sequence of the viral genomic RNA to produce a nested set of mRNAs with common 3' ends. Two or three proteases will be encoded to cleave the replicase polyproteins. During the process of RNA synthesis, a number of the nonstructural proteins gather to the replicase-transcriptase complex, creating a suitable environment and assisting in the synthesis of negativestrand intermediates. Sub-genomic RNA located downstream of replicase polyproteins is the basis of structure and assists gene expression [63]. Homologous and nonhomologous recombination is a feature of coronavirus. It is associated with the strand switching ability of the RdRp and is the basis for virus evolution [64, 65]. With the synthesis of genomic and sub-genomic RNA replication, S, E, and $M$ proteins are translated and then modified and packaged in the endoplasmic reticulum and endoplasmic reticulum-Golgi intermediate compartment
$[66,67]$. Inside the compartment, the viral genome, which is wrapped in the $\mathrm{N}$ protein, buds into the membrane and forms a mature virus [68].

\section{Antiviral drugs for COVID-19 \\ Protease inhibitors \\ Lopinavir/ritonavir}

Lopinavir (LPV) and ritonavir (RTV) are two protease inhibitors with related structure. LPV is an antiretroviral drug that prevents the proliferation of the virus and is widely used in treating human immunodeficiency virus (HIV) infection. LPV can specifically inhibit HIV-1 protease, thereby inhibiting HIV-1 proliferation in host cells and blocking HIV-1 infection. The pesticide effect of LPV can be enhanced by RTV, which presents no effect when used alone against SARS-CoV-2. RTV promotes the efficacy of LPV by decreasing the hepatic metabolism of LPV. The recommended dose of LPV/r, $400 \mathrm{mg} /$ $100 \mathrm{mg}$ twice daily, is based solely on the plasma concentration of LPV, under which LPV can suppress about half of viral replication in immune cells effectively [69]. Drug-drug interaction (DDI) is the main problem of Lopinavir/ritonavir (LPV/r) because they are both substrates and inhibitors of many drug-metabolizing enzymes, like cytochrome P450 3A4, and drug efflux transporters, like P-glycoprotein. Thus, they can be toxic when used with many other medicines [70-72].

Many studies have evaluated the efficacy of $\mathrm{LPV} / \mathrm{r}$. The performance of $\mathrm{LPV} / \mathrm{r}$ in tissue culture models is controversial. A study that screened a library of 348 Food and Drug Administration (FDA)-approved drugs to find drugs with anti-MERS-CoV activity found LPV can inhibit MERS-CoV replication with low-micromolar concentration. However, another study that selected LPV from a chemical library of 1280 kinds of drugs by chemical methods had unsatisfactory in vitro results [73, 74]. In animal studies, the MERS model of common marmoset treated with $\mathrm{LPV} / \mathrm{r}$ showed positive results, including less weight loss, viral titers, and better clinical scores and disease prognosis [75]. LPV alone had 50\% effective concentration (EC50) ranged from 6.6 to 17.1 $\mathrm{mM}$ when used against SARS-CoV, MERS-CoV, and $\mathrm{hCoV}-229 \mathrm{E}$ in vitro [74]. LPV/r was effective for both patients and tissue effected by SARS-CoV. Forty-one patients with SARS received both LPV/r and RBV for 3 weeks and had significantly less adverse outcomes compared with the historical controls [76]. Furthermore, both a nonrandomized open-label trial and a randomized trial found $\mathrm{LPV} / \mathrm{r}$ can improve the clinical outcomes of patients with SARS-CoV [76-78]. There are 59 ongoing studies and 5 completed studies exploring the application of LPV/r in treating COVID-19 (NCT04358614, NCT04343768, NCT04276688, NCT04379245, NCT04374071). Several COVID-19 case series reported ambiguous results, in which 
some patients got a lower viral load and sooner recovery, while others deteriorated [2, 79-81]. Moreover, a randomized, controlled, clinical trial (Chinese Clinical Trial Register number, ChiCTR2000029308) with 199 patients involved found no significant benefit from $\mathrm{LPV} / \mathrm{r}$ treatment [3]. The poor performance of LPV/r in SARS-CoV-2 can be because that the SARS-CoV-2 counterpart (3CLpro) is dissimilar to the HIV aspartic protease [82]. Increasing combination therapies of LPV/r were explored with positive results, including LPV/r with arbidol, ribavirin and IFN- $\beta$ [83-85]. However, there were studies indicated that the combination of $L P V / r$ and IFN- $\beta$ did not have better potency than using IFN- $\beta$ alone [86]. In terms of side effects, $L P V / r$ can increase the occurrence of liver injury, but reduce the occurrence rate of overall death, acute respiratory distress syndrome and nosocomial infection. Due to the lack of large-scale studies about the pesticide effect of LPV/r, many clinicians still advocate the use of LPV/r as it is relatively safe and convenient for deployment [87].

\section{Camostat mesylate}

Camostat mesylate (CM) is a protease inhibitor developed in Japan, in the 1980s, and firstly used for chronic pancreatitis and then postoperative reflux esophagitis with an oral dose of 600 and $300 \mathrm{mg} /$ day, respectively [88-91]. It is now regarded as a potential drug for curing COVID-19, since $S$ protein driven viruses need TMPRSS2 to active $\mathrm{S}$ protein to ensure their entry, and CM can inhibit this process [92-94]. Its efficacy has been approved in cellular level, as it can effectively block the spare of SARS-CoV and HCoV-NL63 into the HeLa cells and the entry of SARS-CoV-2 into the human lung Calu-3 cells $[95,96]$. In a SARS-CoV mouse model experiment, CM effectively protected $60 \%$ mouse from death [91]. In this study, the amount of CM required for humans was $2.14 \mathrm{mg} / \mathrm{kg}$ after converting the human and mouse weights. This dose was considered to be under the safe dose. The plasma half-life of CM is $100 \mathrm{~min}$, and CM almost completely disappears in plasma after 4-5 h. Therefore, taking $600 \mathrm{mg}$ CM daily may be an effective way to control SARSCOV-2 infection. CM is very safe to use in Japan, where 100, 000 people take it each year and few adverse events have been reported [97]. Meanwhile, low cost is the main advantage of CM, taking only $0.1-0.4$ USD for a $100 \mathrm{mg}$ tablet, being especially beneficial to the patients with low-income. Therefore, CM is likely to become an effective treatment for COVID-19 after more clinical trials.

\section{RNA polymerase inhibitor Remdesivir}

Remdesivir (RDV) is a $1^{\prime}$-cyano-substituted adenosine $\mathrm{C}$-nucleotide ribose analogue, developed by Gilead Sciences to cope with Ebola and related viruses. It can inhibit the proliferation of virus by targeting the RNA polymerase and its antiviral activity depends on the active triphosphate metabolite [98, 99]. Compared with other members of 1'-cyano group, whose interference with viral transcription is slowed down by the slow first phosphorylation kinetics, RDV can avoid this barrier as it is a isomeric compound of the 2-ethylbutyl l-alaninate phosphoramidate prodrug [100]. When RDV enters the virus, its triphosphate form, which is similar to ATP, will be used as a substrate for $\operatorname{RdRp}$ in several viruses and interfere the virus proliferation [101-103]. Some studies also reported that in the fight against Ebola, Nipah and respiratory syncytial viruses, RDV mainly delays the termination of new viral RNA strands [101, 103-105]. Moreover, there are many other pathogenic RNA viruses (including Filoviridae, Paramyxoviridae, Pneumoviridae, and Orthocoronavirinae) that can be inhibited by RDV in vitro, suggesting that it has a wide range of potential medical applications [106].

Though RDV had no effect in curing Ebola, it was therapeutic for MERS and SARS both in tissue culture and animal studies $[10,106,107]$. In the cultures of primary human lung epithelial cells, RDV can effectively suppress the proliferation of SARS-CoV and MERS$\mathrm{CoV}$, with EC50 of $0.07 \mathrm{mM}$ [106]. In the mouse model effected by SARS-CoV, RDV can decrease pulmonary viral load and improve both clinical symptoms and respiratory function effectively. On the fourth or fifth day after infection, the virus titer was reduced by two orders of magnitude [108]. In addition, RDV presented high intracellular concentration $(>10 \mathrm{mM})$ in a rhesus monkey Ebola model. Daily intravenous injection of $10 \mathrm{mg}$ /kg RDV could improve the clinical symptoms and pathophysiological indicators. Meanwhile, RDV can prevent and treat the rhesus macaque model with MERS$\mathrm{CoV}$ infection. Lower MERS-CoV replication level and fewer gross and histologic lung lesions existed in the test group with RDV [103, 109]. For mice affected by MERS, RDV was proven to be superior to the combination of $\mathrm{LPV} / \mathrm{r}$ and IFN- $\beta$, and could reduce MERS-CoV replication, acute lung injury, and improve pulmonary function [86]. In the fight against COVID-19, RDV was widely used in the USA and Europe, known as compassionate use. The first COVID-19 case in the USA was successfully cured by RDV on day 7 of hospitalization. Furthermore, it is difficult for $\mathrm{CoV}$ to develop resistance to RDV. In a previous study, which introduced murine hepatitis virus resistance mutations into SARS-CoV, though SARS-CoV gained drug resistance, the pathogenesis of SARS-CoV also decreased [110]. Nevertheless, recent studies reported that there were still some uncertain treatment effects and side effects (like vomiting, nausea, rectal hemorrhage, and hepatic toxicity) of RDV. Thus, more studies are in demand for evaluating the safety of RDV. At present, nine Phase 3 human trials (NCT04315948, NCT04321616, NCT04280705, 
NCT04292730, NCT04292899, NCT04359095, NCT04395170, NCT04361461, NCT04349410) and three Phase 2 human trials (NCT04386447, NCT04330690, NCT04373044) are in progress about using RDV for moderate to severe adult SARS-CoV-2 cases and may have preliminary results soon.

\section{Ribavirin}

Ribavirin (RBV) is a broad-acting antiviral drug and can suppress the viral proliferation by multiple mechanisms. First designed for children with respiratory syncytial virus in the 1980s, it is now also used for viral hemorrhagic fever and in combination with IFN for hepatitis $C$ [85]. It can act as a cytostatic agent to reduce the synthesis of DNA, RNA and proteins in cells [111]. RBV is clinically administered as the nucleoside, which can be converted to ribavirin monophosphate (RMP) by adenosine kinase. The RMP will subsequently be phosphorylated into di- and tri-phosphorylated nucleotides, which is generally the dominating metabolite [112]. In vitro, RBV has a relatively short half-life in cultured fibroblasts and lymphoblasts and a longer half-life in erythrocytes, which is the cause of its side effect, reversible hemolytic anemia [112]. In addition to interfering with polymerase, RBV also promotes RNA degradation by interfering with RNA capping, decreases the stabilization of viral RNA by inhibiting the generation of guanosine, reduces the fidelity of viral nucleic acid replication by introducing random mutations and indirectly fights against virus by mediating the immune system $[113,114]$. Meanwhile, as an immunomodulator, RBV promotes the transformation of $\mathrm{T}$-helper cell phenotype from type 2 to type 1 [114]. Cellular immunity is activated during the T-helper type 1 response and is associated with the expression of interleukin-2 (IL-2), interferon-gamma, and tumor necrosis factor-alpha [115, 116]. In the hepatitis $C$ virus infection, a T-helper 2 response may lead to the development of chronic disease [117]. Thus, the inhibition of a Type- 2 response and promotion of a Type-1 response of RBV can help combat the virus. The pharmacokinetics and bioavailability of RBV in human have been thoroughly studied, and the EC50 of RBV against COVID-19 is much higher than the semi-maximum inhibition concentration of RBV against dengue virus $[118,119]$. In addition, adequate experience in clinical use, easy access to get, relatively affordable price are also the reasons for choosing this drug [120].

In the model of rhesus macaque effected by MERS$\mathrm{CoV}$, the group treated by RBV with IFN- $\alpha 2 \mathrm{~b} 8 \mathrm{~h}$ after inoculation did not develop breathing abnormalities, no or very mild pneumonia sign in radiographic evidence, and low levels of systemic and local proinflammatory markers [121]. However, in a study that included 349 patients under the infection of MERs-CoV, combined use of RBV and IFN on average 2 days after admission to the intensive care unit did not reduce 90-day mortality or accelerate MERS-CoV RNA clearance [122]. In 2003, the results of RBV combined with corticosteroids and/or IFN in the treatment of SARS-COV patients were not optimistic, and many adverse reactions occurred in patients, in particular increased hemolysis and transaminase $[123,124]$. Although RBV shows inhibitory activity at viral load, it is not practical to treat SARS-COV with RBV because this effect is only available at high concentrations $(0.5-5 \mathrm{mg} / \mathrm{mL})$, which have been shown to have cytotoxic effects on VeroE6 cells $[125,126]$. In addition, the dose of RBV required to treat SARS patients (1.2$2.4 \mathrm{~g}$, three times a day) was excessively toxic to patients [127]. Compared with RDV, the in vitro dose (EC50 $109.5 \mathrm{mM}$ ) of RBV for SARS-CoV-2 was 100 times higher than that of RDV [119]. According to the results of cell experiments, the dosage of RBV can be reduced when combined with IFN $[128,129]$. A multicenter, randomized study (NCT04276688) compared the combination use of RBV, LPV/r and IFN- $\beta$ and LPV/r alone. The therapeutic effect of the former was superior to that of the latter [130]. The side effects of RBV are relatively strong, especially hemolytic anemia [123, 131, 132]. A retrospective study in Canada suggested that RBV might not be clinically effective, but could increase the incidence of adverse events and lead to early drug withdrawal [123]. In addition, the US FDA has made it clear that RBV has strict indications and is not recommended for the treatment of influenza [133]. Therefore, there is insufficient evidence to prove the effect of RBV on SARS-CoV-2 based on the current research results [123, 134].

\section{Interferon- $\boldsymbol{a}$}

IFN- $\alpha$ is a broad-spectrum antiviral drug that has been used to treat viral hepatitis and block SARS-CoV virus replication. IFN type-I response and downstream cascade play important roles in innate immune responses, mediating the effective activation of adaptive immune response $[135,136]$. IFN fights against the virus by stimulating multiple immune pathways that include four major factors: 2'-5'-oligoadenylate synthetase (OAS) protein, ribonuclease L (RNase L), double-stranded RNA-dependent protein kinase (PKR), Mx proteins and RNA-specific adenosine deaminase (ADAR)- 1 . OAS protein cooperate with RNase $\mathrm{L}$ and can be activated by dsRNA to polymerize ATP into $2{ }^{\prime}-5^{\prime}$-linked oligoadenylates $(2-5(\mathrm{~A})$ with various length and degrade singlestranded RNA [137]. This antiviral ability of the 2-5(A) synthetase system has been reported in $\mathrm{HCV}$, vaccinia and HIV [138]. In addition, OAS can induce apoptosis by blocking the effects of B-cell leukemia/lymphoma 
(Bcl)-2 and Bcl-xl [139]. PKR can be induced by IFN and is associated with viral dsRNA. Upon activation, PKB inhibits protein synthesis by phosphorylating eukaryotic initiation factor $2 \alpha$ subunits and interferes with a variety of signal transcription pathways, including STAT1 and nuclear factor-KappaB (NF-kB). The activity of IFN is also mediated by PKR, because the mutation or suppression of PKR can influence the anti-EMCV action of type I IFNs [140, 141]. The antiviral ability of Mx proteins does not require collaboration with any other IFNinduced cellular proteins. Mx proteins can interfere with the synthesis of viral RNA and block the transport of viral nucleocapsid by binding to viral proteins and protein-protein interactions, and thus has a wide range of antiviral activity [142-144]. The IFN-inducible ADAR family leads to hypermutability in dsRNA of many viruses because it can substitute adenosines (A) with inosines (I) $[145,146]$. This conversion decreases the stability of dsRNA and inhibits the replication of viruses, including measles, polyomavirus, vesicular stomatitis, and hepatitis D virus $[147,148]$.

At present, IFN- $\alpha$ subtypes are approved for clinical use, including IFN- $\alpha 2 b$, IFN- $\alpha 2 a$, and IFN- $\alpha 1 b$, and IFN- $\alpha 2 b$ has relatively higher activity [149]. In a SARSCoV-2 Vero cell study, IFN- $\alpha$ and IFN- $\beta$ effectively reduced viral titers to the concentration of $1.35 \mathrm{IU} / \mathrm{ml}$ and $0.76 \mathrm{IU} / \mathrm{ml}$, indicating SARS-CoV-2 infection can be inhibited by IFN in cell culture [135]. Although the efficacy of IFN- $\alpha$ has been proved in the clinical trials of MERS infection, a small cohort study found that IFN- $\alpha$ was useful only in the early and intermediate stage of MERS. Several clinical trials are currently under way to evaluate the efficacy of Type-I IFN alone (NCT04293887, NCT04320238, ChiCTR2000029989) or in combination (NCT04254874, NCT04273763, NCT04276688, NCT04343768, NCT04350671) against COVID-19. In a double-blind clinical trial, although low-dose oral IFN failed to cure acute respiratory disease, it did reduce the severity of symptoms and benefit subgroups of patients [150]. In a retrospective singlecenter study involving 94 confirmed COVID-19 patients, therapeutic regimens of IFN- $\alpha+\mathrm{LPV} / \mathrm{r}$ and IFN- $\alpha+$ $\mathrm{LPV} / \mathrm{r}+\mathrm{RBV}$ were found to be beneficial for reducing IL-6 and C-reactive protein levels in COVID-19 patients [151]. A retrospective study of COVID-19 patients treated alone or in combination with IFN- $\alpha 2 b$ and arbidol found similar results. The results showed a decrease in the level of the upper respiratory tract virus and a decrease in the duration of elevated levels of inflammatory markers IL-6 and CRP in the blood. Despite the positive results, the absence of a control group and the baseline mismatch between the groups reduced the reliability of the study results [152]. With regard to IFN for prevention, a prospective study (NCT04320238) recruited 2944 health care workers and classified them into low-risk and high-risk groups based on whether they had direct contact with COVID-19 patients. IFN- $\alpha$ nasal drops were administered to the low-risk group, and IFN- $\alpha$ nasal drops and thymosin-a1 were administered to the high-risk group. In terms of side effects, the main adverse reactions after subcutaneous and intramuscular injection of IFN- $\alpha$ are influenza-like symptoms, bone marrow suppression and mental disorders [153]. Inhalation may reduce systemic side effects but can still cause bronchospasm and prevent normal exhalation. In addition, the dose required by inhalation is relatively large, and IFN- $\alpha$ dose less than $18 \times 10^{6} \mathrm{IU} /$ day is difficult to enter systemic circulation [154]. In completed studies, IFN- $\alpha$ was protective against SARS-CoV-2 and was often used in combination with other antiviral drugs to cure SARS-CoV-2 infection, suggesting it as a potential drug for COVID-19.

\section{Summary of antiviral drugs}

Based on the mechanism of virus invasion, many antiviral drugs have been developed. Different drugs target different processes, including virus recognition, fusion, entry and genomic proliferation to prevent the spread of the virus. ACE2 receptor and protease TMPRSS2 play important roles in the virus recognition and fusion prior to virus entry into host cells. The protease inhibitors LPV/ R and CM, which have been most clinically studied on COVID-19, inhibit the activation of S protein by inhibiting the protease TMPRSS2. After entry, viral genome proliferation is inhibited by nucleotide analogues, like RDV and RBV that target RNA polymerase. In addition, since the invasion and replication of SARS$\mathrm{CoV}-2$ can induce the innate and adaptive immune responses, immunomodulators such as the IFN family can help active more effective immune cells to fight against SARS-CoV-2. Although the efficacy of these drugs has been abundantly studied in previous widely epidemic virus, MERS and SARS-CoV by cell culture, animal experiments and clinical trials, the best option for treating COVID-19 remains unclear. Therefore, more random and multicentral trails are required for better COVID-19 treatment. Besides the efficacy, side effects, cost and availability are also key considerations when choosing a drug. In order to promote the clinical use of these potential drugs, the World Health Organization and the European Union recently initiated clinical trials to test the efficacy of LPV/r plus IFN- $\beta$, RDV, chloroquine and hydroxychloroquine in COVID-19 patients worldwide in the SOLIDARITY Trial (NCT04321616) and the DisCoVeRy Trial (NCT04315948), and promising results may come out soon. 


\section{Immunotherapy}

\section{Corticosteroids}

The clinical efficacy of corticosteroids, a potent regulator in the development of autoimmune disease and inflammatory process, has been verified in various indications. Both the classical pathway mediated by the receptor of corticosteroids that directly combined with glucocorticoid response elements to control certain gene expression and the transcription-independent non-classical pathway that leads to rapid signaling and persistent hormone effect underlies the physiological action of corticosteroids [155]. The advantage of inhibiting the exuberant immune response as well as the progression of pulmonary fibrosis theoretically allows the application in COVID-19 [156], especially for the severe case with acute respiratory distress syndrome (ARDS), the common lethal complication of viral infections in respiratory system [157, 158].

During the SARS and MERS outbreak, corticosteroids have been routinely used to forestall excessive lung damage and respiratory distress caused by hyperactive immune response [156, 157]. However, studies on corticosteroid treatment fail to provide supporting proof for its appropriate use but uncover underlying risks such as the low efficacy of virus clearance in patients with MERS infection $[134,159]$. Observational studies of patients with influenza-associated pneumonia treated with corticosteroids also reported a higher risk of motility and hospitalacquired infection [160-162].

Evidence regarding the effectiveness of corticosteroids also disagreed on their clinical use. Notably, one study found that among 84 patients who developed ARDS out of 201 patients with COVID-19, methylprednisolone treatment significantly decreased the motility by $62 \%$ [163]. Another meta-analysis also attested to such therapeutic benefits in severe patients with ARDS but failed to show a similar conclusion in patients without ARDS [164]. Empiric therapy of corticosteroids in COVID-19 patients without conclusive evidence sometimes failed to exert positive effects on the disease progression. One study analyzed clinical information of 31 patients with COVID-19 and found that corticosteroids did not exert a significant effect on virus clearance and duration of hospitalization [165]. However, two retrospective studies of symptomatic patients suggested the association between corticosteroid treatment and prolonged viral RNA shedding as well as high risk of death [166]. Furthermore, a meta-analysis including 5270 patients indicated that corticosteroid treatment led to longer hospitalization days and higher mortality [79]. Recently, another meta-analysis of patients with SARS-CoV, MERS-CoV, and SARS-CoV2 further demonstrated the increased use of mechanical ventilation under corticosteroid therapy [167]. Although the latest guidance (on the clinical management of
COVID-19) from WHO recommended corticosteroid therapy in the severe and critical case, it also warned against regular administration of corticosteroids except for specific indications such as chronic obstructive pulmonary disease exacerbation or septic shock [168]. Consequently, until now, even though we have primarily recognized the efficacy and risk of corticosteroids in COVID-19 treatment, further research is needed to guide the appropriate use in clinical practice for its existing uncertainties [169].

In conclusion, the efficacy of corticosteroids in COVID19 treatment is a double-edged sword. In clinical practice, the adverse effects of immunomodulation, for instance, immunosuppression and secondary infection, provoke different opinions on the usage of corticosteroid treatment. Now, subject to the limited sample numbers, short followup duration, and different administration plans, clinical evidence does not suffice to yield convincing conclusions, and therefore necessitates the urgent verification of the reasonable use of corticosteroid in large scale randomized controlled trials (RCTs). Two clinical trials (NCT04374071/NCT04273321) on the therapeutic effects of methylprednisolone on COVID-19 have been completed, the result of which has not been published so far. Ongoing clinical trials may provide us with more insights on the indications of corticosteroids in COVID-19 patients, the precise control of the administration time, interval, and appropriate dosage to avoid the potential risk but mitigate the suffering of patients as much as possible.

\section{Anti-cytokine interventions}

Anti-cytokine interventions or other immunomodulatory agents might contribute to mitigating the overactivated host immune response induced by highly active proinflammatory cytokines [170] and further prevent detrimental complications such as ARDS and multiorgan dysfunction in COVID-19 patient [171]. Delayed type I interferon response, responsible for the initiation and amplification of cytokine storm in the COVID-19, activated extensive IFN-stimulated gene expression and recruited various innate immunocytes while various cytokines released further dampen $\mathrm{T}$ cell response that was crucial to the virus clearance [172]. Since the increasing level of IL-6, a pivotal role in the cytokine storm, is highly relevant to respiratory distress or poor outcomes [80, 173, 174], suppressing IL-6 and its receptors could alleviate the disease progression and promote the prognosis. Potential mechanism includes maintaining perforin expression at functional level [175], preventing overactivated Th17 cells [176], inhibiting NF- $\mathrm{B}$ [177] and trans-signaling induced by membrane-bound gp130 which the soluble IL-6-IL-6R interact with [178].

Tocilizumab, a recombinant humanized monoclonal antibody targeting at both soluble and membrane-bound 
IL-6 receptors, is widely applicable to treating various immune-related disorders such as rheumatoid arthritis, adult-onset Still's disease, juvenile idiopathic arthritis, giant cell arteritis, and cytokine release syndrome, a severe complication in chimeric antigen receptor $\mathrm{T}$ cell therapy [179]. A systematic review including both early case reports and retrospective studies of Tocilizumab revealed that it could be a potential promising treatment based on the preliminary result of improved clinical course [180]. More recent studies further attested to the potential benefits of Tocilizumab for COVID-19 patients [181-185]. A single-center prospective study of 100 patients with COVID-19 pneumonia and ARDS requiring respiratory support demonstrated that $77 \%$ of the patients showed great clinical improvement in respiratory function and imageological characteristics of the lung [186]. Another systematic review including 11 case reports of COVID-19 patients indicated that tocilizumab could effectively inhibit the hyper-inflammatory state by downregulating the level of IL-6 and CRP level [187]. In addition to the verification of the clinic effectiveness, a single-center retrospective study compared severe patients undergoing anti-cytokine treatments who later received ventilation with those who did not and suggested that the optimal administration timing for anti-cytokine therapy might be before ventilation in intensive care units (ICUs) [188]. Besides, the positive influence of low dose Tocilizumab $(400 \mathrm{mg}$ ) on 85 patients with COVID19 pneumonia and severe respiratory failure not only supported the clinical effectiveness as well as the safety of this dosage but also proposed that early use in severe cases might promote clinical course and outcomes [189]. However, one new case report introduced two patients with COVID-19-related cytokine storm who received Tocilizumab therapy but later progressed to SHLH and even viral myocarditis, which cast doubt on the safety of Tocilizumab [190]. Even though the National Health Commission of China adopted Tocilizumab in COVID19 therapy recommendations and existing studies have yielded initial conclusions regarding the safety and effectiveness of anti-cytokine interventions, the finding could be biased by a small sample, the effects of other therapies and the absence of randomized groups. To offer more solid evidence for the use of Tocilizumab, many institutions have launched clinical trials to evaluate its efficacy and safety. In addition to 24 registered clinical trials on Tocilizumab, the use of other anticytokine agents in clinic practice such as IL-6 receptor inhibitors (sarilumab), IL-6 inhibitors (siltuximab, clazakizumab, sirukumab), anti-Interleukin-8(BMS-986253), inhibitors of IL-1ra(Anakinra) are now being tested. Moreover, in addition to the clinical use, more proof is required to address the diagnostic criteria of cytokine storm, the disease severity grade, and biomarkers such as cytokine measurement to guide appropriate timing for treatment and predict prognosis [172].

\section{JAK2 inhibitors}

Various kinds of cytokines assume leading roles in the development of immune response by binding cellular receptors from different families and subsequently activating downstream cascade reaction. In particular, cytokine showing high affinity with type I and type II cytokine receptors are effective modulatory agents in immunerelated disorders. They can further attach to the JAKrelated signaling transduction to mediate inflammatory reaction [191].

The four members in the JAK family, JAK1, JAK2, JAK3, and tyrosine kinase-2 could either individually interact with cytokine receptors or selectively form a group with the other three members to exert such function, such as the combination of JAK1 and JAK2 in IFN$\gamma$-relevant signaling transduction [192, 193]. Therefore, the selective inhibitors of JAK have attracted great attention for their use in the inflammation-driven diseases including rheumatoid arthritis (RA), inflammatory bowel disease, and dermatological conditions, even in a few new clinical indications such as COVID-19 [194, 195]. As the potential receptor of 2019-nCov [196-198], ACE2 failed to act as the natural protector of the lung after the virus attack and led to acute lung injury [199]. The high level of inflammatory cytokines might further downregulate the ACE2 and foster the progression of COVID-19 [194, 200]. Therefore, blocking the downstream signal transduction of these inflammatory cytokines might alleviate the negative effects of excessive inflammatory response. Besides, JAK inhibitor of high affinity with AP2-associated protein kinase 1 (AAK1), the regulator mediating the endocytosis of 2019-nCoV, could also be a highly efficient contributor to disrupting the invasion of the virus [201].

In terms of the affinity with AAK1 and the safety of drug dosage, Baricitinib, a novel selective inhibitor of JAK1 and JAK2 [202], is recommended to be a candidate in the COVID-19 treatment [19]. One open-label design in Italy included 12 patients with moderate COVID-19 pneumonia who received a 2-week combined therapy of ritonavir-lopinavir and Baricitinib. Notably, the therapy improved respiratory function and laboratory parameters without adverse effects on the cardiovascular and hematologic system or infection [203]. Several clinical trials have been adopted to justify the safety and effectiveness of Baricitinib in clinical practice (NCT04320277, NCT04321993, NCT04340232, NCT04346147, NCT04345289, NCT04358614, NCT04373044, NCT04393051, NCT04399798, NCT04362943). Nevertheless, some studies challenged clinical use in specific indications including reduction of lymphocyte, elevations of creatine kinase, elderly patients, and secondary 
infections [204], all of which are common in severe and critical patients. Meanwhile, the interference with JAKs signaling transduction also dampens the role of $\alpha$ - and $\beta$ IFN in antiviral response since, as mentioned before, the delayed IFN activation might hinder the efficacy of the virus clearance and worsen the lung inflammation [205].

In addition to Baricitinib, clinical trials focus on other JAK inhibitors such as ruxolitinib (NCT04348695, NCT04361903, NCT04331665, NCT04338958, NCT04337359, NCT04374149, NCT04334044, NCT04377620, NCT04362137, NCT04366232, NCT04355793, NCT04359290, NCT04348071) and tofacitinib (NCT04390061, NCT04332042) have also been initiated to explore the potential effective drugs.

\section{Convalescent plasma therapy}

Convalescent plasma therapy refers to the collection of plasma from convalescent patients with protective antibodies and the transfusion of convalescent plasma to recipients in case of the occurrence of possible lethal complications [206]. In addition to the antibodies inhibiting virus replication, other derivative components in plasma such as anti-inflammatory cytokines could modulate the immune response by blocking complement, which, in particular, might contribute to the disruption of the cytokines storms in COVID-19 [207, 339]. According to the dynamic characteristics of antibodies in immune response among COVID-19 patients, the seroconversion time of IgM and IgG is about 13 days after the symptom onset [208] while the viral load reached the peak within 12 days [209]. Therefore, given the temporary absence of vaccines available for COVID19, passive immunotherapy could defend against SARSCoV-2 until the establishment of effective immune response for specific pathogen. Preclinical evidence has shown that SARS-CoV-2 could induce both cellular and humoral immunity to protect against re-exposure in rhesus macaques [210]. Successful treatment in previous viral pandemics such as hemorrhagic fevers (Ebola) [211], influenza(H1N1 and H5N1) [212-216], and other coronaviruses also implies the promising future of convalescent plasma therapy in COVID-19 [217, 218]. One research in China included 5 critically ill patients with ARDS who received convalescent plasma treatment (titer of SARS-CoV-2-specific antibody> 1:1000; titer of neutralizing antibody $>1: 40)$ from the 10th day to the 22nd day after admission and found that four out of these (4/ $5,80 \%$ ) patients showed improved respiratory, negative viral load, increasing specific antibodies and neutralizing antibodies [219]. To test the effectiveness and safety of immunoglobulin therapy, Duan et.al designed a prospective study that provided combined therapy of antiviral drug and convalescent plasma (titer of neutralizing antibody $>1: 640$ derived from recovered patients for 10 confirmed patients). Apart from significantly improved clinical symptoms and laboratory parameters such as increasing lymphocyte counts and decreasing CRP levels, no detection of virus or adverse effects were observed within 3 days after the initiation of the trial [220]. Nevertheless, despite the approval from FDA of using convalescent plasma in Critically Ill Patients [221], there might be potential hazards we have not been fully aware of, such as the high risk of antibody-dependent enhancement [222], since no large scale RCTs or registered clinical trials weighing the therapeutic benefits and potential risks of convalescent plasma have yielded convincing results [223]. Besides, the acquisition of robust humoral response, management and administration of convalescent plasma, transfusion reactions and reinfection could also be barriers to the clinical use of immunoglobulin therapy [224].

\section{Chloroquine (CQ) and hydroxychloroquine (HCQ)}

Sharing similar chemical functions and therapeutic mechanisms, both CQ and HCQ are primarily anti antimalarial drugs but recently well recognized for its benefits in many various diseases, especially in rheumatic and skin disorders such as RA [225], systemic lupus erythematosus [226] and antiphospholipid syndrome [227]. The possible mechanism for its immunomodulatory and anti-inflammatory effects mainly include:(1) increasing the $\mathrm{PH}$ to inhibit the lysosomal activity and therefore dampening the lysosome-mediated antigen processing [228-230] (2) inhibiting Toll-like receptor (TLR) signaling $[231,232]$ (3) interfering type I IFN response by modulating the activity of cyclic GMP-AMP (cGAMP) synthase [233] (4). reducing the production of proinflammatory cytokines of macrophage [234-236]. CQ and HCQ also possess antiviral properties by interfering with the different stages of virus replication:(1) suppressing glycosylation of ACE2, the target shared by both SARSCoV-1 and SARS-CoV-2 [198] (2) destruction of the $\mathrm{PH}$-dependent virus-endosome fusion to inhibit the release of virus RNA [237] (3) impairing proteolytic processes and glycosylation to interfere with the posttranscriptional modification [238, 239]. However, while some studies have reported the antiviral activity in HIV [240, 241], Zika virus [242], influenza virus [243], MERS-CoV [74], and SARS-CoV-1 [244], opposing opinions always exist arguing the uncertain role of $C Q$ and HCQ in vivo studies. In mice and cat models, CQ did not present a significant antiviral effect though it might participate in the modulation of the immune response [235, 245].

Recent experiments in vitro also demonstrated that both HCQ and CQ could effectively block the virus replication in Vero cells infected with SARS-CoV-2 at low concentration $[87,119,246]$. But few in vivo studies 
have yielded meaningful data to support the conclusion. In one research, while patients receiving either azithromycin or hydroxychloroquine had a lower rate of virus clearance, those following combined treatment showed a negative nasopharyngeal swab after 6 days [247]. Another research aimed to replicate such amazing therapeutic benefits by executing the same design in 11 patients but failed [248]. According to a meta-analysis [249] reviewing the current seven studies evaluating the antiviral property in patents, five gave support to the efficacy of HCQ or CQ while the other two did not. In one study, a multicenter, open-label, randomized controlled clinical trial including 150 patients, 75 patients received $1200 \mathrm{mg}$ HCQ treatment for 3 days, and then followed a daily maintenance dose of $800 \mathrm{mg}$ in addition to standard of care assigned to the control group. While 56 patients in the control group displayed positive conversion, 53 patients in the experiment group showed negative conversion within 28 days. Besides, adverse events were higher in the hydroxychloroquine treatment group (21/70,30\% versus $7 / 80,9 \%)$. Therefore, there are no significant beneficial effects of HCQ treatment on negative conversion but a higher chance to suffer adverse events [250]. A similar observational study acquired a similar conclusion that neither the mortality nor the composite endpoint of intubation was related to the hydroxychloroquine treatment [251]. The latest study comparing 1438 COVID-19 patients who received HCQ and Azithromycin respectively, or the combination of the two with the control group indicated that no significant difference of the in-hospital death among the four treatment groups was observed but the possibility of cardiac arrest significantly increased in patients following combined treatment [252]. Registered clinical trials were recruiting volunteers to test the efficacy and safety of CQ and HCQ at different dosages in prevention and treatment combined with other drugs or without.

Although these studies have primarily provided some initial evidence for the use in the clinic, the data available now could not sufficiently warrant the application of CQ or HCQ in clinical practice nor against them. Therefore, even if some guidelines recommend an emergent use of $\mathrm{HCQ}$ or $\mathrm{CQ}$, results of well-designed clinical trials are urgently needed to verify the feasibility of HCQ treatment on COVID-19 patients as well as instructions for proper administration to avoid severe adverse effects such as gastrointestinal symptoms, neurologic side effects, cardiomyopathy and conduction disturbances [253].

\section{The IFN family}

Apart from the antiviral property described above, IFN also acts as a modulatory agent in both innate and adaptive response. IFN contributes to the enhancement of the cytotoxic activity of natural killer cells [254, 255], growth and differentiation of dendritic cells (DC) [256], and regulation of $\mathrm{T}$-cell and B-cell response [257, 258]. In addition to the traditional use in $\mathrm{HBV}$ and $\mathrm{HCV}$ [259], IFN also proves to be effective in treating SARS$\mathrm{CoV}$-related infection. For instance, the combined therapy of IFN-1 and glucocorticoid could improve oxygen saturation and radiographic lung abnormalities in SARS patients [260]. For COVID-19, combined therapy of IFN and other antiviral drugs have achieved some initial results. Among patients who received combined treatment of IFN- $\alpha+$ lopinavir/ritonavir or IFN- $\alpha+$ lopinavir/ritonavir + ribavirin, the mRNA clearance rate was in positive correlation with hospitalization length, which might imply the benefits of combined treatment [151]. Ongoing clinic trials may further reveal the promising future of IFN in COVID-19 treatment. Some studies also discussed the possible beneficial effect of interferon lambda on virus load decrease as well as suppression of hyperactive inflammation response [261, 262]. Meanwhile, among 4 completed clinical trials (NCT04343768, NCT04389645, NCT04291729, NCT04276688), an open-Label, randomized, phase 2 trial (NCT04276688) published their result that early combined therapy of IFN $\beta-1 b$, Lopinavir-Ritonavir, and Ribavirin improved clinic course, accelerated viral shedding and shortened hospitalization length in patients with mild symptoms, which implied the efficacy of interferon beta- $1 \mathrm{~b}$ as a backbone in antiviral therapy [130].

\section{Intravenous immunoglobulin (IVIG)}

Extracted IgG from thousands of healthy plasma donors, Intravenous immunoglobulin preparations contain both immune antibodies for replacement therapy and passive immunity and physiologic autoantibodies for immunomodulation [263]. While the efficacy of IVIG has been verified in immune-related and neurological disorders, it's hard to develop a clear systematic understanding of the mechanism. The potential therapeutic benefit mainly depends on the two functional domains of IgG, F (ab')2 and $\mathrm{Fc}$ and fragment, the function of which including cellular receptor blockade, suppression of Fc gamma receptors expression and activation, a saturation of the neonatal Fc receptor, regulation of cytokines, complements and immunocytes, Fc-dependent immunomodulatory pathway $[207,264,265]$.

While according to a systematic review [134], two studies focusing on the effectiveness of IVIG during SARS were inconclusive [266, 267], preclinical evidence primarily demonstrated that antibodies in intravenous immunoglobulins could crossreact against SARS-CoV-2 [268]. Xie et.al first reported their retrospective study of 58 severe or critical patients who receive IVIG as adjuvant treatment within $48 \mathrm{~h}$ or more than $48 \mathrm{~h}$ after 
admission to ICUs and found that IVIG treatment within $48 \mathrm{~h}$ could improve their ventilation function, reduce hospitalization length and 28-day mortality [269]. Also, two case reports claimed successful IVIG treatment in COVID-19 patients [270, 271]. While these positive results may provide preliminary evidence for IVIG treatment in COVID patients, more large scale prospective randomized controlled trials would further warrant the use. Following clinical trials (NCT04383548, NCT04400058, NCT04261426, NCT04264858, NCT04350580) plan to test the therapeutic effect of various immunoglobulin on COVID-19 patients and provide more convincing proof regarding the use.

\section{Summary of immunotherapy}

Inflammation is conducive to the elimination of pathogens in the immune response. However, in the severe case of COVID-19, SARS-CoV-2 could induce an excessive immune response and cytokine storm, which finally leads to lethal complications such as ARDS and multiple-organ dysfunction. While the antiviral drugs and symptomatic therapy remain the major treatment, immunomodulatory therapy including corticosteroids, anti-cytokine agents, JAK inhibitors, chloroquine, hydroxychloroquine, convalescent plasma, IVIG and IFN, could alleviate the local or systemic inflammation injury and further prevent the progress of COVID-19.

However, the major issue regarding the use of immunomodulatory agents is the proper administration timing, safe and effective dosage, and clinical indications. Immunomodulatory agents could sometimes inhibit the immune response and engender secondary infection or delay the pathogen clearance. Besides, since severe cases tend to suffer hyper inflammation and soon deterioration, the onset of the antiinflammation therapy is crucial for reversing the conditions. Finally, in addition to the perplexing mechanism of these therapies, conflicting evidence regarding the effectiveness further refrain clinic use.

Observation studies currently available subject to limited sample numbers, short follow-up duration and different administration plan fails to provide convincing conclusions supporting the wide application in larger groups of patients. Besides, no clinical trials or literature focusing on the therapeutic effects of immunomodulatory agents on the COVID-19 patients have achieved an agreement so far. Therefore, without official guidance, the clinicians must caution against the use of immune therapy and give personal administration based on the overall evaluation of the patient's disease condition, for instance, the appropriate medication time and dosage.

\section{Other therapies}

\section{Mesenchymal stem cells}

Mesenchymal stem cells (MSCs) are generally prepared from MSCs isolated from unrelated donor bone marrow and amplified in culture [272, 273]. MSCs have now been shown to have immunomodulatory effects when administered via intravenous infusion [274]. The antiinflammatory effect is achieved by down-regulating the production of pro-inflammatory cytokines and increasing the production of paracrine and anti-inflammatory cytokines for tissue repair. What' more, MSCs can recruit natural anti-inflammatory cells into relevant tissues to fight the inflammatory processes associated with many diseases [78]. Preclinical evidence suggests that MSCs have the ability to restore endothelial cell permeability and reduce inflammatory infiltration. Although the immunomodulatory role of MSCs has been demonstrated on avian influenza viruses, their role in COVID19 is still being evaluated [188]. Currently, There were some clinical trials to evaluate the efficacy of MSCs which were from the umbilical cord and pulp (NCT04293692, NCT04269525, NCT04288102, NCT04302519) [275-277].

Mesoblast LTD has been approved by the FDA for a new drug clinical trial application for its allogeneic cell therapy Ryoncil (remestemcel-L). Administration via intravenous infusion for the treatment of acute respiratory distress syndrome in patients with COVID-19. In the study, which was conducted in over 1100 patients, the safety and therapeutic efficacy of intravenous administration of remestemcel- $\mathrm{L}$ have been evaluated. These patients had a variety of inflammatory diseases, including elderly patients with lung disease, adult and pediatric steroid-refractory acute graft-versus-host disease, chronic graft-versus-host disease, biologically agentrefractory Crohn's disease, hypoxic-ischemic encephalopathy, and herpetic epidermolysis [275, 276, 278]. Studies have shown that the cytokine storm process produced by COVID-19 is similar to aGVHD. In addition, a study of 60 patients with chronic obstructive pulmonary disease showed that remestemcel-L had the obvious ability to improve respiratory function in patients with the same elevated inflammatory biomarkers that were also observed in patients with COVID-19 ARDS [279]. These provide a theoretical basis for the treatment of COVID-19 by remestemcel-L.

Leng et al. showed that homozygous ACE2-MSC transplantation was effective in improving the prognosis of COVID-19 [280]. In seven patients with COVID-19 who received a single intravenous MSC graft, the results showed that MSC cured or significantly improved lung function in these 7 patients within 14 days of transplantation, with no significant adverse effects. In addition, MSCs are known to exhibit significant 
immunomodulatory functions. On day 4 after transplantation, C-reactive protein levels in critically ill patients decreased from a maximum of $191.0 \mathrm{~g} / \mathrm{L}$ to $13.6 \mathrm{~g} /$ $\mathrm{L}$, and absolute lymphocyte counts increased to $0.58 \times$ $10^{9}$, indicating rapid remission of inflammation, significant improvement in lymphocyte reduction, and return to normal biochemical indicators of liver and heart function [280].

\section{Herbal medicine}

In previous treatment experience, herbal medicine has a role in preventing SARS and H1N1 influenza. There are two common prescriptions: Yupingfeng Powder and Sangju Decoction. Some studies have shown that Yupingfeng Powder has antiviral, anti-inflammatory and immunomodulatory effects $[281,282]$. The main use of the herb is for upper respiratory infections, antibacterial and antiviral effects, improving the immune system of the upper respiratory tract mucous membrane.

In the treatment of H1N1 influenza is, commonly used Qingjie Fanggan Granule, Ganmao Qingre Granule, Kangbingdu Oral Liquid. In a meta-analysis, the infection rate was significantly lower in patients taking these herbal formulations than in the control group. Relative risk (RR) $0.36,95 \%$ confidence Interval $0.24-0.52, P<$ 0.01 . A total of 54 different herbs are currently in use in herbal remedies [196, 283-285]. Astragalus and licorice are used the most. However, the mechanism of herbal treatment is currently unclear and strong evidence is lacking. The formulas used vary from province to province. But the safety of herbal medicine use is of great concern. The formulas used are different for different ages, so be sure to use them under the guidance of your doctor. There should be more retrospective, RCT studies in the future to evaluate the preventive role of herbs in COVID-19.

\section{Vaccines}

Because of the enormous impact of COVID-19 on human health, research institutes in various countries have been developing vaccines. The first candidate 2019 coronavirus vaccine entered human clinical testing at an unprecedented rate on March 16, 2020. Evaluation of the next generation of vaccine technology platforms is also being promoted through new models [286-288].

\section{mRNA vaccine}

The mRNA vaccine is the delivery of mRNA to cells that express the protein that produces it, thereby expanding the immunity of the organism [288]. It does not require any nuclear localization signal, transcription, and integration into the genome is not possible, which avoids any possible therapeutic mutations $[289,290]$. There are two main types of mRNA vaccines available, those that are self-amplifying and those that are non-replicating mRNA [291]. Self-amplifying mRNA vaccines are usually based on the genome of the genus alphavirus, where the gene encoding the RNA replication mechanism is intact and the structural protein-coding gene of the protovirus is replaced with mRNA encoding the antigenic protein [292, 293]. Non-replicating mRNA vaccines are in vitro transcribed sections of complete mRNA encoding antigenic proteins, including $5^{\prime}$ and $3^{\prime}$ untranslated regions, and poly(A) tail to stabilize the mRNA and promote transcription [294, 295]. The mRNA vaccine is synthesized by in vitro transcription techniques using plasmid DNA or other DNA fragments containing the open reading frame of the target protein as a template [296].

Since mRNAs contain cap structures at the $5^{\prime}$ end and Poly(A) at the $3^{\prime}$ end, the addition of these components is generally required after in vitro transcription of the synthesized mRNA. There are also many current studies on the synthesis of mRNA vaccines in vitro by chemical modification. And for mRNA vaccine delivery, it can be done by electroporation, liposome nanoparticle delivery system, polymer delivery system [297-300]. For example, Nucleoside-modified mRNA greatly improves mRNA stability and can regulate the half-life of mRNA drugs in vivo; liposomal nanoparticles can envelope mRNA, further improving stability and also efficiently complete intracellular delivery of mRNA [296, 301].

The first candidate COVID-19 vaccine was mRNA1273 developed by Moderna. After Chinese scholars shared the gene sequence of the SARS-CoV-2 on January 11, 2020, NIH and Moderna began development of the mRNA-1273 vaccine with funding from The Coalition for Epidemic Preparedness Innovations (CEPI). On February 7, production of the first clinical batch of the vaccine was completed, and on March 4, a Phase I clinical trial was approved by the FDA. This experiment provided important data on the safety and immunogenicity of mRNA-1273 by recruiting 45 healthy adult volunteers aged 18 to 55 years.

The clinical phase I trial conducted by Moderna had three dose groups, $25 \mu \mathrm{g}, 100 \mu \mathrm{g}, 250 \mu \mathrm{g}$, and expanded the six groups in the older and the elder. On May 7, the FDA approved the study for a Phase II clinical trial. A third phase of the study is planned for early summer. The platform used for this vaccine is mRNA. In past studies, the safety of Phase I clinical trial species of five other respiratory viruses (two pandemic influenza viruses, RSV, hMPV, and PIV3) has been proved [302, 303]. mRNA is an information molecule, and Moderna used the sequence of the virus to design messenger RNA vaccines, rather than studying the virus itself. mRNA platforms have significant advantages in terms of speed and efficiency. mRNA can span basic science, manufacturing, and clinical development. After verifying the 
safety and efficacy of mRNA-1273, it will be put into mass production. On May 18, data from the Phase I clinical trial published on Moderna's webpage showed that, after two doses, all participants in the $25 \mu \mathrm{g}$ and $100 \mu \mathrm{g}$ dose cohorts evaluated to date had seroconversion rates that met or exceeded the levels of conjugated antibodies in their recovery serum. In the $25 \mu \mathrm{g}$ and $100 \mu \mathrm{g}$ dose cohorts, mRNA-1273 elicited neutralizing antibody titers in all eight initial participants, meeting or exceeding the neutralizing antibody titers typically seen in recovery serum. mRNA-1273 was overall safe and well tolerated. The only grade 3 adverse event that occurred in the $25 \mu \mathrm{g}$ and $100 \mu \mathrm{g}$ dose cohorts was a grade 3 erythema around the injection site in a participant in the $100 \mu \mathrm{g}$ dose group. By far, the most notable adverse events occurred at the $250 \mu \mathrm{g}$ dose level, with three participants experiencing grade 3 systemic symptoms only after the second dose. All adverse events are transient and can resolve themselves. No grade 4 adverse events or serious adverse events are reported [304].

\section{DNA vaccine}

DNA vaccines are delivered into the body and are taken up by surrounding tissue cells (e.g., myocytes), antigenpresenting cells (APCs) or other inflammatory cells [305]. Plasmid DNA molecules ingested by tissue cells such as myocytes are then transcribed into mRNA in the nucleus, which is then moved into the cytoplasm for translation into antigenic protein molecules [306]. The antigenic protein molecules released by the cells into the tissue interstitium are captured by APCs and processed into antigen-peptide delivery to $\mathrm{T}$ cells, initiating an immune response [307]. APCs from peripheral lymphatic organs also directly uptake nucleic acid vaccines, express antigens and deliver them to $\mathrm{T}$ cells, triggering an immune response. Dendritic cells are the most important antigen-delivering cells in nucleic acid immunity, while $\mathrm{B}$ cells are not involved in the antigen-delivering process [308]. After triggering an immune response, the cytotoxic T-cell (CTL) response recognizes and kills myocytes expressing exogenous antigens, causing myocytes to lyse and release intracellular antigens, which APC obtains directly from the injection site to initiate the subsequent immune response. The combination of several pathways allows the DNA vaccine to stimulate $\mathrm{T}$ lymphocytes via the histocompatibility complexes MHC I and MHC II, and to activate B lymphocytes. Tissue cells such as myocytes may act as storage plasmids and regular release during the immune process $[25,309]$.

Inovio had developed a Phase 2 vaccine for Middle Eastern respiratory syndrome-related coronavirus, has designed INO-4800 using the DNA medicines platform. INO-4800 matches the DNA sequence of the virus precisely. On April 20th, Clinical Phase I trial has been approved by the FDA. DNA medicine consists of optimized DNA plasmids or recombined by computer sequencing techniques and designed to produce specific immune responses in the human body. Inovio's DNA drugs use Inovio's patented handheld smart device, CELLECTRA $^{\circ}$, to deliver optimized plasmids directly into cells by intramuscular or intradermal injections.

CELLECTRA uses a short electrical pulse to reversibly opens small pores in the cell to allow plasmids to enter by using a short electrical pulse to reversibly. Once in the cell, the plasmids begin to replicate, thus reinforcing natural response mechanisms. The use of CELLECTRA device makes sure that the DNA drug enters cells directly, where it can immediately initiate an immune response. Inovio's DNA drugs do not interfere with or alter a person's DNA in any way. The advantages of Inovio's DNA drug platform are fast development and production of DNA drugs, good product stability, no refrigeration for storage and transport, strong immune response, safety and tolerability.

\section{Recombination vaccine}

The main mechanism of recombinant COVID-19 vaccines (adenovirus vectors) is the use of genetic engineering techniques to introduce and express genes encoding pathogenic protective antigens into adenovirus vaccines [310]. The first step is to select the highly characteristic protein structures on the surface of the pathogenic virus, that is, these protein structures stimulate the immune system to produce antibodies. For coronaviruses, the protrusion on the surface of the viral shell (S protein) is a target protein. Next, find the gene that encodes the $S$ protein $[311,312]$. For DNA viruses, the corresponding DNA fragment can be found directly; for RNA viruses, the corresponding RNA has to be found and translated into DNA fragments [313, 314]. What' more, the encoded genes are fused into the DNA of the adenovirus and allowed to enter the human cell via the adenovirus as a vector. Finally, these coding genes synthesize some of the characteristic proteins of the pathogenic virus in the body, which induces strong humoral and cellular immunity and induces the body to produce specific antibodies, which are people's immunity against the pathogenic virus [315].

\section{Ad5-nCoV}

Ad5- $\mathrm{nCoV}$, a recombinant vaccine (adenovirus vector type 5) studied by the Beijing Institute of Biotechnology and three other Chinese research institutions with support from CanSino Biologics Inc. [316]. A clinical phase I trial (NCT04313127) has already started on March 15, 2020, which is a single-center, open-label, doseescalating, phase I clinical trial in a healthy population aged 18 to 60 years to assess the safety, adverse effects 
and immunogenicity of a novel recombinant coronavirus vaccine. One hundred eight volunteers were assigned to three groups and received either an intramuscular injection of the experimental vaccine in the deltoid muscle or a placebo. The experimental group was divided into high school and low three dose groups, and the estimated completion time of this clinical trial is December 2020.

The study conducted by Wei Chen et al. was published in The Lancet on May 22nd, and the safety, tolerability and immunogenicity of $\mathrm{Ad} 5-\mathrm{nCoV}$ were reported [317]. The main findings so far show that Ad5- $\mathrm{nCoV}$ is safe, well-tolerated in humans, and able to cause the immune response of immune system to COVID-19. Further trials will be required to assess whether the vaccine is effective in preventing neocoronavirus infection. In the article, it was reported that within 7 days of $\mathrm{Ad} 5-\mathrm{nCoV}$ vaccination, 30 people in the low-dose group (83\%), 30 people in the medium-dose group, 30 People $(83 \%)$ and 27 people (75\%) in the high dose group experienced at least one adverse effect. These adverse reactions included more than half $(54 \%, 58 / 108)$ of the vaccines experiencing mild pain at the injection site. Fever $(46 \%, 50 / 108)$, fatigue $(44 \%, 47 / 108)$, headache $(39 \%, 42 / 108)$ and muscle pain $(17 \%, 18 / 108)$. The results showed that each dose of vaccine was well tolerated and no serious adverse reactions were reported within 28 days after inoculation. Most adverse events were mild or moderate.

Reports of immunogenicity of Ad5-nCoV showed that within 14 days of vaccination, a certain level of immune response was triggered and antibodies were produced in the vaccines. The specific ratios were $16 / 36,44 \%$, in the low-dose group; $18 / 36,50 \%$, in the medium-dose group; $22 / 36,61 \%$, in the high-dose group. Antibodies were produced at detectable levels in some subjects; the vaccine also triggered $\mathrm{T}$-cell response. Twenty-eight days after vaccination, $\mathrm{T}$-cell responses, or detectable levels of neutralizing antibodies, were present in the majority of vaccines. The specific ratios were: $28 / 36,78 \%$ in the low-dose group, 33/36, $92 \%$ in the medium-dose group, $36 / 36,100 \%$ in the high-dose group. The researchers also found that if pre-existing immunity to adenovirus Ad5 existed in the subjects, the vaccine could be Weakening, such as reduced peak levels of immune responses and shortened persistence of immune responses.

Only 108 volunteers were involved in this study, and the short duration of the trial, as well as the lack of randomized controls, made it difficult to detect Adverse events, or the discovery of limitations in the protective power of vaccines. A phase II, randomized, double-blind, controlled clinical trial involving 500 volunteers is currently underway in Wuhan to see if the results of this phase I clinical trial can be replicated and if adverse events occur within 6 months of vaccination. What' more, the population who are 60 years of age was also involved as subjects, for the first time.

\section{ChAdOx1 nCoV-19}

ChAdOx1 nCoV-19, developed at the University of Oxford, consists of a non-replicating adenovirus vector and the $\mathrm{S}$ protein gene sequence of SARS-CoV-2 and is in Phase I/II clinical trials (NCT04324606). Adenovirus does not replicate in the host, making it relatively safe in children and individuals with underlying diseases. In addition, based on the carrier of adenovirus has extensive organization orientation, including respiratory and gastrointestinal epithelium, both express the ACE of SARS$\mathrm{CoV}-2$ main parts of the receptor. Should always consider the carrier gene, however, rather than the possibility of genetically modified dominant immunogenicity [318].

According to the current results of animal experiments on ChAdOx1 nCoV-19 in rhesus monkeys, ChAdOx1 $n \mathrm{CoV}-19$ vaccine does not prevent macaque monkeys from contracting the virus, nor does it prevent animals from spreading the infection to other animals. In this study, six rhesus macaques were vaccinated with the ChA$\mathrm{dOx} 1 \mathrm{nCoV}-19$ vaccine, and after 28 days were exposed to the SARS-CoV-2 virus. The researchers also compared them to three unvaccinated monkeys. As determined by the recovery of viral genomic RNA in nasal secretions, the researchers determined that all six macaques that were vaccinated with the vaccine were infected with the COVID-19. Compared with unvaccinated animals, the amount of viral RNA detected from this site in vaccinated rhesus monkeys had no difference.

\section{COVID-19 synthetic Minigene vaccine}

DC and CTL cells play a key role in viral clearance during the immune process, so it is important to induce vaccines that produce strong, long-lasting, cross- $\mathrm{T}$ cell responses [319-322]. This minigene can express a segment of amino acid residue peptide through viral infection or the synthesis of a minigene. Infected cells can sensitize immune cells and stimulate T-cell activity [323, 324].

Based on a detailed analysis of the viral genome and the finding for latent immunogenic targets, a synthetic mini-protein based on the conserved structural domains of viral structural proteins and multiprotein proteases was synthesized by the Shenzhen Geno-Immune Medical Institute. COVID-19 infection is mediated by binding of the spike protein to the ACE2 receptor and viral replication depends on the molecular mechanism of all these viral proteins. This experiment intends to use the efficient lentiviral vector system (NHP/TYF) to develop and test a novel COVID-19 mini-genome based on a variety of viral genes, express viral proteins and immunoregulatory genes, modify DCs, and activate $\mathrm{T}$ cells 

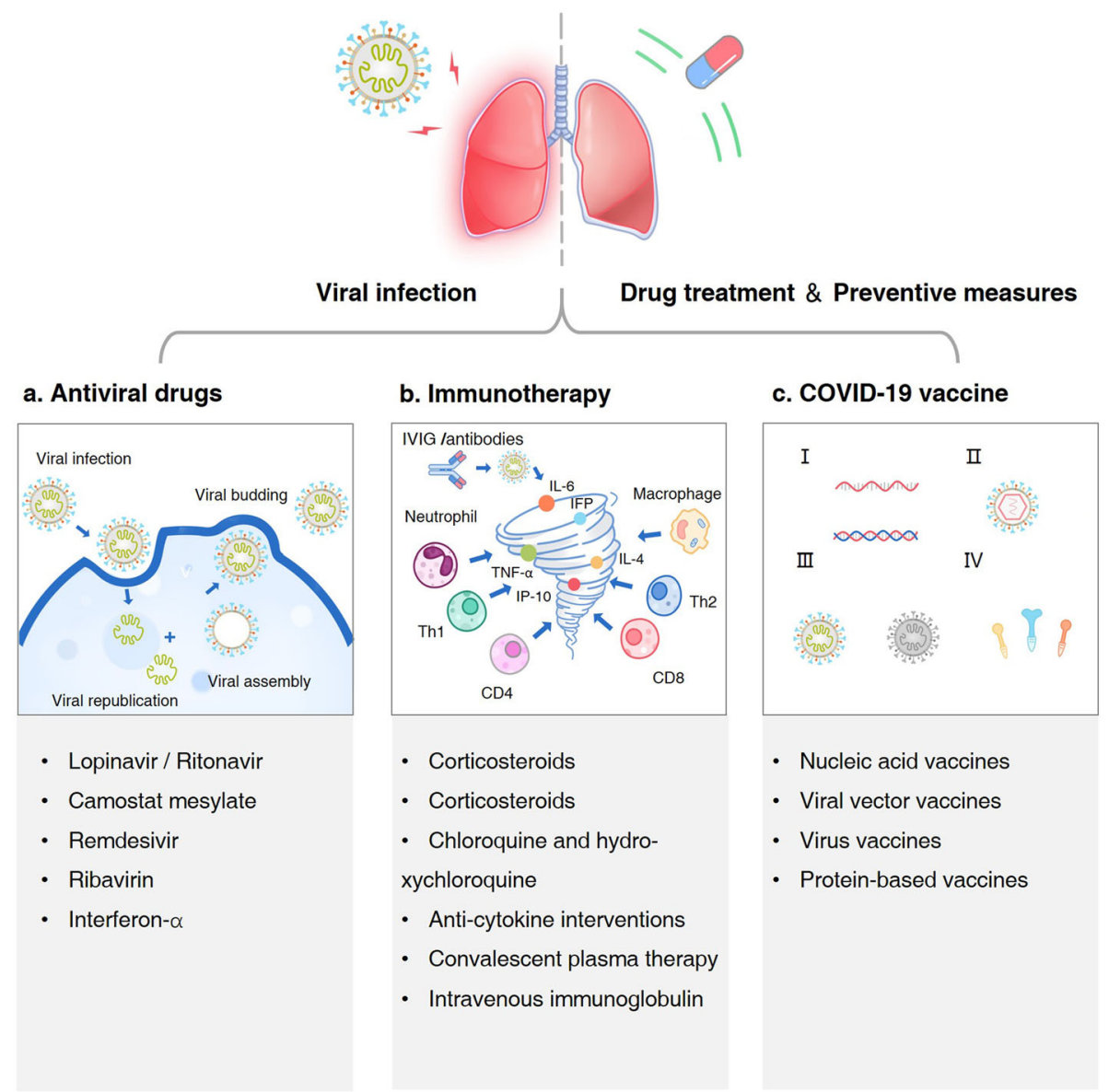

Fig. 2 A brief overview of drug treatment and preventive measures. Antiviral drugs: Lopinavir, ritonavir, and camostat mesylate are two protease inhibitors, and the pesticide effect of lopinavir improves when combined with ritonavir usage. Remdesivir, a nucleotide analogue, can inhibit the proliferation of the virus by targeting the RNA polymerase. It can act as a nucleotide analogue, an immunomodulator, and promote RNA degradation. Interferon-a can inhibit the virus by multiple immune pathways. Immunotherapy: Corticosteroids prevent the overactive immune response as well as the progression of pulmonary fibrosis. Chloroquine and hydroxychloroquine act as an immunomodulatory agent by dampening the lysosome-mediated antigen processing, inhibiting Toll-like receptor signaling, interfering with type I IFN response, and reducing the production of proinflammatory cytokines. Anti-cytokine interventions contribute to suppressing the lung injury caused by the cytokine storm. Convalescent plasma therapy and Intravenous immunoglobulin can enhance passive immune response as well as provide other derivative components in plasma to modulate immunity. COVID-19 vaccine: Nucieic acid vaccines include DNA and RNA. The platform of viral vector vaccines is adenovirus type 5 vector. Virus vaccines have codon deoptimized live attenuated and inactivated SARS-Cov + Alum. Protein-based vaccines are full-length recombinant SARS CoV-2 glycoprotein and nanoparticle vaccine adjuvanted with Matrix M

[325]. In this study (NCT04276896), the safety and efficacy of the LV vaccine (LV- SMENP) will be investigated.

\section{Summary of vaccines}

A feature of the COVID-19 vaccine development field is the search for a wide range of platforms, including nucleic acids (DNA and RNA), virus-like particles, peptides, viral vectors (replicated and non-replicated), recombinant proteins, attenuated live viruses and inactivated virus methods [326, 327]. Although many of the methods are not vectors used in conventional vaccine studies, they may work well for specific populations (such as elderly, pregnant women, children) [328-330]. For some platforms, adjuvants can enhance immunogenicity and make low doses feasible, allowing more people to be vaccinated without compromising protection [331, 332]. Ten researchers have already started this study. Common adjuvants are AS03, MF59 and CpG 1018 which are made by GlaxoSmithKline, Seqirus and Dyna$\operatorname{vax}[3,333-335]$.

The COVID vaccine is expected to be in use by early 2021, which could reduce the 10-year lead time for a conventional vaccine to be successfully developed at a time when a lot of manpower and resources are currently being invested [336, 337]. Current accelerated 
vaccine development through parallel and adaptive development phases, innovative regulatory processes and expanded manufacturing capabilities $[25,338]$.

\section{Conclusion}

Under the currently emergent state of global health conditions resulting from COVID-19, effective therapies are desirably needed. The review introduced possible therapeutical treatments and their underlying mechanism against the SARS-CoV-2 infection (Fig. 2). Research on the repurpose of antiviral drugs has acquired some preliminary results proving their efficacy in forestalling virus reproduction at different stages or blocking specific targets including Lopinavir/ritonavir, Ribavirin and Remdesivir. Furthermore, given the hyper inflammation response mediated by the dysregulation of the immune system, the anti-inflammation or immunomodulatory agents are expected to play roles in preventing deterioration. However, despite the theoretical feasibility, the proper administration timing, safe and effective dosage, and clinical indications remains to be undetermined and therefore require a cautious assessment of the patient's health conditions before administration to avoid potential adverse effects. Besides, we also updated the newest progress for both other adjuvant treatments such as herbal therapies or mesenchymal stem cell therapies and the vaccine under different stages of clinical trials which soon will be in use to alleviate the heavy burden of increasingly worsening global health conditions and economic plight. Nevertheless, due to the current absence of conclusive proof to support the recommendation for specific therapies or vaccines in the clinical practice, further researches and large scales clinical trials might serve to equip clinicians with more valid information regarding the efficacy and pharmacokinetics of specific therapy of vaccines and therefore optimize their clinical strategies.

\footnotetext{
Abbreviations

AAK1: AP2-associated protein kinase 1; ACE2: Angiotensin-converting enzyme 2; ADAR: RNA-specific adenosine deaminase; APCs: Antigen-presenting cells; ARDS: Acute respiratory distress syndrome; CM: Camostat mesylate; COVID19: Coronavirus disease 2019; CQ: Chloroquine; CRP: C-reactive protein; CT: Computed tomography; CTD: C-terminal domain; CTL: Cytotoxic T-cell; DCs: Dendritic cells; EC50: 50\% effective concentration; FDA: Food and Drug Administration; hACE2: Human ACE2; HCQ: Hydroxychloroquine; HIV: Human immunodeficiency virus; ICUs: Intensive care units; IFN: Interferon; IL6: Interleukin-6; IFN: Interferon; IVIG: Intravenous immunoglobulin; JAK: Janus kinase; LPV/r: Lopinavir/ritonavir; MERS: Middle East respiratory syndrome; MERS-CoV: Middle East respiratory syndrome coronavirus; MSCs: Mesenchymal stem cells; NF-KB: Nuclear factor-KappaB; OAS: Oligoadenylate synthetase; PKR: Double-stranded RNA-dependent protein kinase; RA: Rheumatoid arthritis; RCTs: Randomized controlled trials; RMP: Ribavirin monophosphate; RNase L: Ribonuclease L; RR: Relative risk; RTPCR: Reverse transcriptase-polymerase chain reaction; RTV: Ritonavir; SARS: Severe acute respiratory syndrome; SARS-CoV: Severe acute respiratory syndrome coronavirus; SARS-CoV-2: Severe acute respiratory syndrome coronavirus 2; SB: Domain B of spike protein; TLR: Toll-like receptor; TMPRSS2: Transmembrane protease/ serine subfamily member 2
}

\section{Acknowledgements}

Not applicable.

\section{Authors' contributions}

XLM provided the idea and designed the study. YNX, HYX, and WG drafted the manuscript. YNZ and YLL designed and illustrated the Fig. MW, ZYH, ZYD and JYL participated in the coordination of the study and edited the manuscript. LD and FSS performed manuscript review. The authors have reviewed and approved the manuscript before submission.

\section{Funding}

Not applicable.

\section{Availability of data and materials \\ Not applicable.}

\section{Ethics approval and consent to participate}

Not applicable.

\section{Consent for publication}

Not applicable.

\section{Competing interests}

The authors declare no conflict of interests.

\section{Author details}

'Department of Biotherapy, State Key Laboratory of Biotherapy, West China Hospital, Sichuan University, Chengdu 610041, China. ${ }^{2}$ West China School of Medicine, West China Hospital, Sichuan University, Chengdu 610041, China. ${ }^{3}$ West China Hospital, Sichuan University, Chengdu 610041, China. Infectious Diseases Center, West China Hospital, Sichuan University, Chengdu 610041, China. ${ }^{5}$ Department of Pharmacy, State Key Laboratory of Biotherapy and Cancer Center, National Clinical Research Center for Geriatrics, West China Hospital, Sichuan University, and Collaborative Innovation Center of

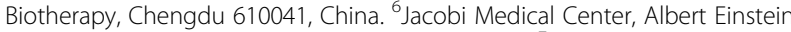
College of Medicine, Bronx, New York 10465, USA. 'Department of Internal Medicine, State University of New York, Downstate Medical Center, Brooklyn, New York 11203, USA.

Received: 4 July 2020 Accepted: 11 November 2020

Published online: 03 December 2020

\section{References}

1. de Wit E, van Doremalen N, Falzarano D, Munster VJ. SARS and MERS: recent insights into emerging coronaviruses. Nat Rev Microbiol. 2016;14(8): 523-34. https://doi.org/10.1038/nrmicro.2016.81.

2. Lim J, Jeon S, Shin HY, Kim MJ, Seong YM, Lee WJ, et al. Case of the index patient who caused tertiary transmission of COVID-19 infection in Korea: the application of lopinavir/ritonavir for the treatment of COVID-19 infected pneumonia monitored by quantitative RT-PCR. J Korean Med Sci. 2020;35(6): e79. https://doi.org/10.3346/jkms.2020.35.e79.

3. Cao B, Wang Y, Wen D, Liu W, Wang J, Fan G, et al. A trial of lopinavirritonavir in adults hospitalized with severe Covid-19. N Engl J Med. 2020; 382(19):1787-99. https://doi.org/10.1056/NEJMoa2001282.

4. Phan TJ. Novel coronavirus: from discovery to clinical diagnostics. Infect Genet Evol. 2020;79:104211. https://doi.org/10.1016/j.meegid.2020.104211.

5. Yao TT, Qian JD, Zhu WY, Wang Y, Wang GQ. A systematic review of lopinavir therapy for SARS coronavirus and MERS coronavirus-a possible reference for coronavirus disease-19 treatment option. J Med Virol. 2020; 92(6):556-63. https://doi.org/10.1002/jmv.25729.

6. $X u X W, W u X X$, Jiang $X G, X u K J$, Ying $L J, M a C L$, et al. Clinical findings in a group of patients infected with the 2019 novel coronavirus (SARS-Cov-2) outside of Wuhan, China: retrospective case series. BMJ (Clinical research ed). 2020;368:m606. https://doi.org/10.1136/bmj.m606.

7. Ahn DG, Shin HJ, Kim MH, Lee S, Kim HS, Myoung J, et al. Current status of epidemiology, diagnosis, therapeutics, and vaccines for novel coronavirus disease 2019 (COVID-19). J Microbiol Biotechnol. 2020;30(3):313-24. https:// doi.org/10.4014/jmb.2003.03011.

8. Liu YJ, Yang YL, Xu Y. What we learned from SARS may provide important insights into understanding and management of coronavirus disease 2019. 
Zhonghua Jie He He Hu Xi Za Zhi. 2020;43(4):339-44. https://doi.org/10. 3760/cma.j.cn112147-20200218-00119.

9. Misra DP, Agarwal V, Gasparyan AY, Zimba O. Rheumatologists' perspective on coronavirus disease 19 (COVID-19) and potential therapeutic targets. Clin Rheumatol. 2020;39(7):2055-62. https://doi.org/10.1007/s10067-020-05073-9.

10. Kupferschmidt K, Cohen J. Race to find COVID-19 treatments accelerates. Science (New York, NY). 2020;367(6485):1412-3. https://doi.org/10.1126/ science.367.6485.1412.

11. Lu H. Drug treatment options for the 2019-new coronavirus (2019-nCoV). Biosci Trends. 2020;14(1):69-71. https://doi.org/10.5582/bst.2020.01020.

12. Guan WJ, Ni ZY, Hu Y, Liang WH, Ou CQ, He JX, et al. Clinical characteristics of coronavirus disease 2019 in China. N Engl J Med. 2020;382(18):1708-20. https://doi.org/10.1056/NEJMoa2002032.

13. Li H, Wang YM, Xu JY, Cao B. Potential antiviral therapeutics for 2019 novel coronavirus. Zhonghua Jie He He Hu Xi Za Zhi. 2020;43(3):170-2. https://doi. org/10.3760/cma.j.issn.1001-0939.2020.03.004.

14. Pan F, Ye T, Sun P, Gui S, Liang B, Li L, et al. Time course of lung changes at chest $C T$ during recovery from coronavirus disease 2019 (COVID-19). Radiology. 2020;295(3):715-21. https://doi.org/10.1148/radiol.2020200370

15. Holshue ML, DeBolt C, Lindquist S, Lofy KH, Wiesman J, Bruce $H_{\text {, }}$ et al. First case of 2019 novel coronavirus in the United States. N Engl J Med. 2020;382(10):929-36. https://doi.org/10.1056/ NEJMoa2001191.

16. Chakraborty C, Sharma AR, Sharma G, Bhattacharya M, Lee SS. SARS-CoV-2 causing pneumonia-associated respiratory disorder (COVID-19): diagnostic and proposed therapeutic options. Eur Rev Med Pharmacol Sci. 2020;24(7): 4016-26. https://doi.org/10.26355/eurrev_202004_20871.

17. Scavone C, Brusco S, Bertini M, Sportiello L, Rafaniello C, Zoccoli A, et al. Current pharmacological treatments for COVID-19: What's next? Br J Pharmacol. 2020;177(21):4813-24. https://doi.org/10.1111/bph.15072

18. Shoenfeld Y. Corona (COVID-19) time musings: our involvement in COVID19 pathogenesis, diagnosis, treatment and vaccine planning. Autoimmun Rev. 2020;19(6):102538. https://doi.org/10.1016/j.autrev.2020.102538.

19. Stebbing J, Phelan A, Griffin I, Tucker C, Oechsle O, Smith D, et al. COVID-19: combining antiviral and anti-inflammatory treatments. Lancet Infect Dis. 2020;20(4):400-2. https://doi.org/10.1016/s1473-3099(20)30132-8.

20. McKee DL, Sternberg A, Stange U, Laufer S, Naujokat C. Candidate drugs against SARS-CoV-2 and COVID-19. Pharmacol Res. 2020;157:104859. https:// doi.org/10.1016/.jphrs.2020.104859.

21. Vabret N, Britton GJ, Gruber C, Hegde S, Kim J, Kuksin M, et al. Immunology of COVID-19: current state of the science. Immunity. 2020;52(6):910-41. https://doi.org/10.1016/j.immuni.2020.05.002.

22. Zaman W, Saqib S, Ullah F, Ayaz A, Ye J. COVID-19: phylogenetic approaches may help in finding resources for natural cure. Phytother Res. 2020. https://doi.org/10.1002/ptr.6787.

23. Khan $S$, Ali A, Shi H, Siddique R, Shabana NG, et al. COVID-19: clinical aspects and therapeutics responses. Saudi Pharm J. 2020;28(8):1004-8. https://doi.org/10.1016/j.jsps.2020.06.022.

24. Lurie N, Saville M, Hatchett R, Halton J. Developing COVID-19 vaccines at pandemic speed. N Engl J Med. 2020;382(21):1969-73. https://doi.org/10. 1056/NEJMp2005630.

25. Sharpe HR, Gilbride C, Allen E, Belij-Rammerstorfer S, Bissett C, Ewer K, et al. The early landscape of coronavirus disease 2019 vaccine development in the UK and rest of the world. Immunology. 2020;160(3):223-32. https://doi. org/10.1111/imm.13222.

26. Ge XY, Li JL, Yang XL, Chmura AA, Zhu G, Epstein JH, et al. Isolation and characterization of a bat SARS-like coronavirus that uses the ACE2 receptor. Nature. 2013;503(7477):535-8. https://doi.org/10.1038/nature12711.

27. Hu B, Zeng LP, Yang XL, Ge XY, Zhang W, Li B, et al. Discovery of a rich gene pool of bat SARS-related coronaviruses provides new insights into the origin of SARS coronavirus. PLoS Pathog. 2017;13(11):e1006698. https://doi. org/10.1371/journal.ppat.1006698.

28. Li W, Shi Z, Yu M, Ren W, Smith C, Epstein JH, et al. Bats are natural reservoirs of SARS-like coronaviruses. Science. 2005;310(5748):676-9. https:// doi.org/10.1126/science.1118391.

29. Yang XL, Hu B, Wang B, Wang MN, Zhang Q, Zhang W, et al. Isolation and characterization of a novel bat coronavirus closely related to the direct progenitor of severe acute respiratory syndrome coronavirus. J Virol. 2015; 90(6):3253-6. https://doi.org/10.1128/JVI.02582-15.

30. Guan $Y$, Zheng BJ, He YQ, Liu XL, Zhuang ZX, Cheung $C L$, et al. Isolation and characterization of viruses related to the SARS coronavirus from animals in southern China. Science. 2003;302(5643):276-8. https://doi.org/10.1126/ science.1087139.

31. Kan B, Wang $M$, Jing $H$, Xu H, Jiang $X$, Yan M, et al. Molecular evolution analysis and geographic investigation of severe acute respiratory syndrome coronavirus-like virus in palm civets at an animal market and on farms. J Virol. 2005;79(18):11892-900. https://doi.org/10.1128/JVl.79.18.11892-11900.2005.

32. Duan L, Zheng Q, Zhang H, Niu Y, Lou Y, Wang H. The SARS-CoV-2 spike glycoprotein biosynthesis, structure, function, and antigenicity: implications for the design of spike-based vaccine immunogens. Front Immunol. 2020; 11:576622. https://doi.org/10.3389/fimmu.2020.576622.

33. Zhu N, Zhang D, Wang W, Li X, Yang B, Song J, et al. A novel coronavirus from patients with pneumonia in China, 2019. N Engl J Med. 2020;382(8): 727-33. https://doi.org/10.1056/NEJMoa2001017.

34. Prompetchara E, Ketloy C, Palaga T. Immune responses in COVID-19 and potential vaccines: lessons learned from SARS and MERS epidemic. Asian Pac J Allergy Immunol. 2020;38(1):1-9. https://doi.org/10.12932/AP-200220-0772.

35. Tortorici MA, Veesler D. Structural insights into coronavirus entry. Adv Virus Res. 2019;105:93-116. https://doi.org/10.1016/bs.aivir.2019.08.002.

36. Belouzard S, Chu VC, Whittaker GR. Activation of the SARS coronavirus spike protein via sequential proteolytic cleavage at two distinct sites. Proc Natl Acad Sci U S A. 2009;106(14):5871-6. https://doi.org/10.1073/pnas. 0809524106.

37. Bosch BJ, van der Zee R, de Haan CA, Rottier PJ. The coronavirus spike protein is a class I virus fusion protein: structural and functional characterization of the fusion core complex. J Virol. 2003;77(16):8801-11. https://doi.org/10.1128/jvi.77.16.8801-8811.2003.

38. Burkard C, Verheije MH, Wicht O, van Kasteren SI, van Kuppeveld FJ, Haagmans BL, et al. Coronavirus cell entry occurs through the endo - /lysosomal pathway in a proteolysis-dependent manner. PLoS Pathog. 2014;10(11):e1004502. https://doi.org/10.1371/journal.ppat.1004502.

39. Kirchdoerfer RN, Cottrell CA, Wang N, Pallesen J, Yassine HM, Turner HL, et al. Pre-fusion structure of a human coronavirus spike protein. Nature. 2016;531(7592):118-21. https://doi.org/10.1038/nature17200.

40. Millet JK, Whittaker GR. Host cell entry of Middle East respiratory syndrome coronavirus after two-step, furin-mediated activation of the spike protein. Proc Natl Acad Sci U S A. 2014;111(42):15214-9. https://doi.org/10.1073/pnas.1407087111.

41. Millet JK, Whittaker GR. Host cell proteases: critical determinants of coronavirus tropism and pathogenesis. Virus Res. 2015;202:120-34. https:// doi.org/10.1016/j.virusres.2014.11.021.

42. Park JE, Li K, Barlan A, Fehr AR, Perlman S, McCray PB Jr, et al. Proteolytic processing of Middle East respiratory syndrome coronavirus spikes expands virus tropism. Proc Natl Acad Sci U S A. 2016;113(43):12262-7. https://doi. org/10.1073/pnas.1608147113.

43. Walls AC, Tortorici MA, Bosch BJ, Frenz B, Rottier PJM, DiMaio F, et al. Cryoelectron microscopy structure of a coronavirus spike glycoprotein trimer. Nature. 2016;531(7592):114-7. https://doi.org/10.1038/nature16988.

44. Gui M, Song W, Zhou H, Xu J, Chen S, Xiang Y, et al. Cryo-electron microscopy structures of the SARS-CoV spike glycoprotein reveal a prerequisite conformational state for receptor binding. Cell Res. 2017;27(1): 119-29. https://doi.org/10.1038/cr.2016.152.

45. Pallesen J, Wang N, Corbett KS, Wrapp D, Kirchdoerfer RN, Turner HL, et al. Immunogenicity and structures of a rationally designed prefusion MERS-CoV spike antigen. Proc Natl Acad Sci U S A. 2017;114(35):E7348-E57. https://doi. org/10.1073/pnas.1707304114.

46. Song W, Gui M, Wang X, Xiang Y. Cryo-EM structure of the SARS coronavirus spike glycoprotein in complex with its host cell receptor ACE2. PLoS Pathog. 2018;14(8):e1007236. https://doi.org/10.1371/journal.ppat.1007236.

47. Madu IG, Roth SL, Belouzard S, Whittaker GR. Characterization of a highly conserved domain within the severe acute respiratory syndrome coronavirus spike protein S2 domain with characteristics of a viral fusion peptide. J Virol. 2009:83(15):7411-21. https://doi.org/10.1128/JVI.00079-09.

48. Heald-Sargent T, Gallagher T. Ready, set, fuse! The coronavirus spike protein and acquisition of fusion competence. Viruses. 2012;4(4):557-80. https://doi. org/10.3390/v4040557.

49. Hulswit RJG, Lang Y, Bakkers MJG, Li W, Li Z, Schouten A, et al. Human coronaviruses OC43 and HKU1 bind to 9-O-acetylated sialic acids via a conserved receptor-binding site in spike protein domain a. Proc Natl Acad Sci U S A. 2019;116(7):2681-90. https://doi.org/10.1073/pnas.1809667116.

50. Tortorici MA, Walls AC, Lang Y, Wang C, Li Z, Koerhuis D, et al. Structural basis for human coronavirus attachment to sialic acid receptors. Nat Struct Mol Biol. 2019;26(6):481-9. https://doi.org/10.1038/s41594-019-0233-y. 
51. Vlasak R, Luytjes W, Spaan W, Palese P. Human and bovine coronaviruses recognize sialic acid-containing receptors similar to those of influenza $C$ viruses. Proc Natl Acad Sci U S A. 1988;85(12):4526-9. https://doi.org/10. 1073/pnas.85.12.4526.

52. Li W, Hulswit RJG, Widjaja I, Raj VS, McBride R, Peng W, et al. Identification of sialic acid-binding function for the Middle East respiratory syndrome coronavirus spike glycoprotein. Proc Natl Acad Sci U S A. 2017;114(40): E8508-E17. https://doi.org/10.1073/pnas.1712592114.

53. Lu G, Hu Y, Wang Q, Qi J, Gao F, Li Y, et al. Molecular basis of binding between novel human coronavirus MERS-CoV and its receptor CD26. Nature. 2013;500(7461):227-31. https://doi.org/10.1038/nature12328.

54. Kirchdoerfer RN, Wang N, Pallesen J, Wrapp D, Turner HL, Cottrell CA, et al. Stabilized coronavirus spikes are resistant to conformational changes induced by receptor recognition or proteolysis. Sci Rep. 2018;8(1):15701. https://doi.org/10.1038/s41598-018-34171-7.

55. Li F, Li W, Farzan M, Harrison SC. Structure of SARS coronavirus spike receptor-binding domain complexed with receptor. Science. 2005;309(5742): 1864-8. https://doi.org/10.1126/science.1116480.

56. Rossen JW, de Beer R, Godeke GJ, Raamsman MJ, Horzinek MC, Vennema H, et al. The viral spike protein is not involved in the polarized sorting of coronaviruses in epithelial cells. J Virol. 1998;72(1):497-503. https://doi.org/ 10.1128/JVI.72.1.497-503.1998.

57. Reguera J, Mudgal G, Santiago C, Casasnovas JM. A structural view of coronavirus-receptor interactions. Virus Res. 2014;194:3-15. https://doi.org/ 10.1016/j.virusres.2014.10.005

58. Xiong X, Tortorici MA, Snijder J, Yoshioka C, Walls AC, Li W, et al. Glycan shield and fusion activation of a deltacoronavirus spike glycoprotein fine-tuned for enteric infections. J Virol. 2018;92(4). https://doi.org/10.1128/JM.01628-17.

59. Traggiai E, Becker S, Subbarao K, Kolesnikova L, Uematsu Y, Gismondo MR, et al. An efficient method to make human monoclonal antibodies from memory B cells: potent neutralization of SARS coronavirus. Nat Med. 2004; 10(8):871-5. https://doi.org/10.1038/nm1080.

60. Corti D, Zhao J, Pedotti M, Simonelli L, Agnihothram S, Fett C, et al. Prophylactic and postexposure efficacy of a potent human monoclonal antibody against MERS coronavirus. Proc Natl Acad Sci U S A. 2015;112(33): 10473-8. https://doi.org/10.1073/pnas.1510199112.

61. Prajapat M, Sarma P, Shekhar N, Prakash A, Avti P, Bhattacharyya A, et al. Update on the target structures of SARS-CoV-2: a systematic review. Indian J Pharm. 2020;52(2):142-9. https://doi.org/10.4103/ijp.IJP_338_20.

62. Wrapp D, Wang N, Corbett KS, Goldsmith JA, Hsieh CL, Abiona O, et al. Cryo-EM structure of the 2019-nCoV spike in the prefusion conformation. Science. 2020;367(6483):1260-3. https://doi.org/10.1126/science.abb2507.

63. Sethna PB, Hofmann MA, Brian DA. Minus-strand copies of replicating coronavirus mRNAs contain antileaders. J Virol. 1991;65(1):320-5. https://doi. org/10.1128/JVI.65.1.320-325.1991.

64. Keck JG, Makino S, Soe LH, Fleming JO, Stohlman SA. Lai MM. RNA recombination of coronavirus. Adv Exp Med Biol. 1987;218:99-107. https:// doi.org/10.1007/978-1-4684-1280-2_11.

65. Lai MM, Baric RS, Makino S, Keck JG, Egbert J, Leibowitz JL, et al, Recombination between nonsegmented RNA genomes of murine coronaviruses. J Virol. 1985;56(2):449-56. https://doi.org/10.1128/JVI.56.2.449456.1985.

66. Krijnse-Locker J, Ericsson M, Rottier PJ, Griffiths G. Characterization of the budding compartment of mouse hepatitis virus: evidence that transport from the RER to the Golgi complex requires only one vesicular transport step. J Cell Biol. 1994;124(1-2):55-70. https://doi.org/10.1083/jcb.124.1.55.

67. Tooze J, Tooze S, Warren G. Replication of coronavirus MHV-A59 in saccells: determination of the first site of budding of progeny virions. Eur J Cell Biol. 1984;33(2):281-93. https://doi.org/10.1016/S0140-6736(02)41295-0.

68. Masters PS. The molecular biology of coronaviruses. Adv Virus Res. 2006;66: 193-292. https://doi.org/10.1016/S0065-3527(06)66005-3.

69. Cvetkovic RS, Goa KL. Lopinavir/ritonavir: a review of its use in the management of HIV infection. Drugs. 2003;63(8):769-802. https://doi.org/10. 2165/00003495-200363080-00004.

70. Khatri A, Dutta S, Wang H, Podsadecki T, Trinh R, Awni W, et al. Evaluation of drug-drug interactions between hepatitis $C$ antiviral agents ombitasvir, paritaprevir/ritonavir, and dasabuvir and HIV-1 protease inhibitors. Clin Infect Dis. 2016;62(8):972-9. https://doi.org/10.1093/cid/civ1213.

71. Siccardi M, Marzolini C, Seden K, Almond L, Kirov A, Khoo S, et al. Prediction of drug-drug interactions between various antidepressants and efavirenz or boosted protease inhibitors using a physiologically based pharmacokinetic modelling approach. Clin Pharmacokinet. 2013;52(7):583-92. https://doi.org/ 10.1007/s40262-013-0056-7.

72. Bergshoeff AS, Fraaij PL, Ndagijimana J, Verweel G, Hartwig NG, Niehues T, et al. Increased dose of lopinavir/ritonavir compensates for efavirenzinduced drug-drug interaction in HIV-1-infected children. J Acquir Immune Defic Syndr. 2005;39(1):63-8. https://doi.org/10.1097/01.qai.0000155203. 89350.85.

73. Chan JF, Chan KH, Kao RY, To KK, Zheng BJ, Li CP, et al. Broad-spectrum antivirals for the emerging Middle East respiratory syndrome coronavirus. Inf Secur. 2013;67(6):606-16. https://doi.org/10.1016/j.jinf.2013.09.029.

74. de Wilde AH, Jochmans D, Posthuma CC, Zevenhoven-Dobbe JC, van Nieuwkoop S, Bestebroer TM, et al. Screening of an FDA-approved compound library identifies four small-molecule inhibitors of Middle East respiratory syndrome coronavirus replication in cell culture. Antimicrob Agents Chemother. 2014;58(8):4875-84. https://doi.org/10.1128/aac.0301114.

75. Chan JF, Yao Y, Yeung ML, Deng W, Bao L, Jia L, et al. Treatment with lopinavir/ritonavir or interferon-beta1b improves outcome of MERS-CoV infection in a nonhuman primate model of common marmoset. J Infect Dis. 2015;212(12):1904-13. https://doi.org/10.1093/infdis/jiv392.

76. Chu CM, Cheng VC, Hung IF, Wong MM, Chan KH, Chan KS, et al. Role of lopinavir/ritonavir in the treatment of SARS: initial virological and clinical findings. Thorax. 2004;59(3):252-6. https://doi.org/10.1136/thorax.2003.012658.

77. Zumla A, Chan JF, Azhar El, Hui DS, Yuen KY. Coronaviruses - drug discovery and therapeutic options. Nat Rev Drug Discov. 2016;15(5):327-47. https:// doi.org/10.1038/nrd.2015.37.

78. Choy KT, Wong AY, Kaewpreedee P, Sia SF, Chen D, Hui KPY, et al. Remdesivir, lopinavir, emetine, and homoharringtonine inhibit SARS-CoV-2 replication in vitro. Antivir Res. 2020;178:104786. https://doi.org/10.1016/j. antiviral.2020.104786.

79. Yang Z, Liu J, Zhou Y, Zhao X, Zhao Q, Liu J. The effect of corticosteroid treatment on patients with coronavirus infection: a systematic review and meta-analysis. J Inf Secur. 2020;81(1):e13-20. https://doi.org/10.1016/j.jinf. 2020.03.062.

80. Young BE, Ong SWX, Kalimuddin S, Low JG, Tan SY, Loh J, et al. Epidemiologic features and clinical course of patients infected with SARSCoV-2 in Singapore. JAMA. 2020;323(15):1488-94. https://doi.org/10.1001/ jama.2020.3204

81. Kim JY, Choe PG, Oh Y, Oh KJ, Kim J, Park SJ, et al. The first case of 2019 novel coronavirus pneumonia imported into Korea from Wuhan, China: implication for infection prevention and control measures. J Korean Med Sci. 2020;35(5):e61. https://doi.org/10.3346/jkms.2020.35.e61.

82. UI Qamar MT, Alqahtani SM, Alamri MA, Chen LL. Structural basis of SARSCoV-2 3CL(pro) and anti-COVID-19 drug discovery from medicinal plants. J Pharm Anal. 2020;10(4):313-9. https://doi.org/10.1016/j.jpha.2020.03.009.

83. Deng L, Li C, Zeng Q, Liu X, Li X, Zhang H, et al. Arbidol combined with $L P V / r$ versus $L P V / r$ alone against corona virus disease 2019: a retrospective cohort study. J Inf Secur. 2020;81(1):e1-5. https://doi.org/10.1016/j.jinf.2020. 03.002.

84. Jean SS, Lee PI, Hsueh PR. Treatment options for COVID-19: the reality and challenges. J Microbiol Immunol Infect. 2020;53(3):436-43. https://doi.org/10. 1016/j.jmii.2020.03.034

85. Martinez MA. Compounds with therapeutic potential against novel respiratory 2019 coronavirus. Antimicrob Agents Chemother. 2020;64(5): e00399-20. https://doi.org/10.1128/aac.00399-20.

86. Sheahan TP, Sims AC, Leist SR, Schafer A, Won J, Brown AJ, et al. Comparative therapeutic efficacy of remdesivir and combination lopinavir, ritonavir, and interferon beta against MERS-CoV. Nat Commun. 2020;11(1): 222. https://doi.org/10.1038/s41467-019-13940-6.

87. Liu J, Cao R, Xu M, Wang X, Zhang H, Hu H, et al. Hydroxychloroquine, a less toxic derivative of chloroquine, is effective in inhibiting SARS-COV-2 infection in vitro. Cell Discovery. 2020;6:16. https://doi.org/10.1038/s41421-020-0156-0.

88. Sai JK, Suyama M, Kubokawa Y, Matsumura Y, Inami K, Watanabe S. Efficacy of camostat mesilate against dyspepsia associated with non-alcoholic mild pancreatic disease. J Gastroenterol. 2010;45(3):335-41. https://doi.org/10. 1007/s00535-009-0148-1.

89. Yamawaki H, Futagami S, Kaneko K, Agawa S, Higuchi K, Murakami M, et al. Camostat mesilate, pancrelipase, and rabeprazole combination therapy improves epigastric pain in early chronic pancreatitis and functional dyspepsia with pancreatic enzyme abnormalities. Digestion. 2019;99(4):28392. https://doi.org/10.1159/000492813. 
90. Ramsey ML, Nuttall J, Hart PA, Team TI. A phase 1/2 trial to evaluate the pharmacokinetics, safety, and efficacy of $\mathrm{NI}-03$ in patients with chronic pancreatitis: study protocol for a randomized controlled trial on the assessment of camostat treatment in chronic pancreatitis (TACTIC). Trials. 2019;20(1):501. https://doi.org/10.1186/s13063-019-3606-y.

91. Ikeda S, Manabe M, Muramatsu T, Takamori K, Ogawa H. Protease inhibitor therapy for recessive dystrophic epidermolysis bullosa. In vitro effect and clinical trial with camostat mesylate. J Am Acad Dermatol. 1988;18(6):124652. https://doi.org/10.1016/s0190-9622(88)70130-9.

92. Matsuyama S, Nagata N, Shirato K, Kawase M, Takeda M, Taguchi F. Efficient activation of the severe acute respiratory syndrome coronavirus spike protein by the transmembrane protease TMPRSS2. J Virol. 2010;84(24): 12658-64. https://doi.org/10.1128/JVI.01542-10

93. Shulla A, Heald-Sargent T, Subramanya G, Zhao J, Perlman S, Gallagher T. A transmembrane serine protease is linked to the severe acute respiratory syndrome coronavirus receptor and activates virus entry. J Virol. 2011;85(2):873-82. https:/doi. org/10.1128/JVl.02062-10.

94. Glowacka I, Bertram S, Muller MA, Allen P, Soilleux E, Pfefferle S, et al. Evidence that TMPRSS2 activates the severe acute respiratory syndrome coronavirus spike protein for membrane fusion and reduces viral control by the humoral immune response. J Virol. 2011;85(9):4122-34. https://doi.org/10.1128/JVI.02232-10.

95. Kawase M, Shirato K, van der Hoek L, Taguchi F, Matsuyama S. Simultaneous treatment of human bronchial epithelial cells with serine and cysteine protease inhibitors prevents severe acute respiratory syndrome coronavirus entry. J Virol. 2012;86(12):6537-45. https://doi.org/10.1128/JVI.00094-12.

96. Ragia G, Manolopoulos VG. Inhibition of SARS-CoV-2 entry through the ACE2/TMPRSS2 pathway: a promising approach for uncovering early COVID19 drug therapies. Eur J Clin Pharmacol. 2020:1-8. https://doi.org/10.1007/ s00228-020-02963-4.

97. Ota S, Hara Y, Kanoh S, Shinoda M, Kawano S, Fujikura Y, et al. Acute eosinophilic pneumonia caused by camostat mesilate: the first case report Respir Med Case Rep. 2016;19:21-3. https://doi.org/10.1016/j.rmcr.2016.06. 005.

98. Cho A, Saunders OL, Butler T, Zhang L, Xu J, Vela JE, et al. Synthesis and antiviral activity of a series of 1'-substituted 4-aza-7,9-dideazaadenosine Cnucleosides. Bioorg Med Chem Lett. 2012;22(8):2705-7. https://doi.org/10. 1016/j.bmcl.2012.02.105.

99. Tchesnokov EP, Feng JY, Porter DP, Gotte M. Mechanism of inhibition of Ebola virus RNA-dependent RNA polymerase by remdesivir. Viruses. 2019; 11(4):326. https://doi.org/10.3390/v11040326.

100. Murakami E, Niu C, Bao H, Micolochick Steuer HM, Whitaker T, Nachman T, et al. The mechanism of action of beta-D-2'-deoxy-2'-fluoro-2'-Cmethylcytidine involves a second metabolic pathway leading to beta-D-2'deoxy-2'-fluoro-2'-C-methyluridine 5'-triphosphate, a potent inhibitor of the hepatitis C virus RNA-dependent RNA polymerase. Antimicrob Agents Chemother. 2008;52(2):458-64. https://doi.org/10.1128/AAC.01184-07.

101. Jordan PC, Liu C, Raynaud P, Lo MK, Spiropoulou CF, Symons JA, et al. Initiation, extension, and termination of RNA synthesis by a paramyxovirus polymerase. PLoS Pathog. 2018;14(2):e1006889. https://doi.org/10.1371/ journal.ppat.1006889.

102. Gordon CJ, Tchesnokov EP, Feng JY, Porter DP, Gotte M. The antiviral compound remdesivir potently inhibits RNA-dependent RNA polymerase from Middle East respiratory syndrome coronavirus. J Biol Chem. 2020; 295(15):4773-9. https://doi.org/10.1074/jbc.AC120.013056.

103. Warren TK, Jordan R, Lo MK, Ray AS, Mackman RL, Soloveva V, et al. Therapeutic efficacy of the small molecule GS-5734 against Ebola virus in rhesus monkeys. Nature. 2016;531(7594):381-5. https://doi.org/10.1038/ nature17180.

104. Lo MK, Jordan R, Arvey A, Sudhamsu J, Shrivastava-Ranjan P, Hotard AL, et al. GS-5734 and its parent nucleoside analog inhibit filo-, pneumo-, and paramyxoviruses. Sci Rep. 2017;7:43395. https://doi.org/10.1038/srep43395.

105. Tchesnokov EP, Raeisimakiani P, Ngure M, Marchant D, Gotte M. Recombinant RNA-dependent RNA polymerase complex of Ebola virus. Sci Rep. 2018;8(1):3970. https://doi.org/10.1038/s41598-018-22328-3.

106. Brown AJ, Won JJ, Graham RL, Dinnon KH 3rd, Sims AC, Feng JY, et al. Broad spectrum antiviral remdesivir inhibits human endemic and zoonotic deltacoronaviruses with a highly divergent RNA dependent RNA polymerase. Antivir Res. 2019;169:104541. https://doi.org/10.1016/j.antiviral.2019.104541.

107. Ko WC, Rolain JM, Lee NY, Chen PL, Huang CT, Lee PI, et al. Arguments in favour of remdesivir for treating SARS-CoV-2 infections. Int J Antimicrob Agents. 2020;55(4):105933. https://doi.org/10.1016/j.ijantimicag.2020.105933.
108. Sheahan TP, Sims AC, Graham RL, Menachery VD, Gralinski LE, Case JB, et al. Broad-spectrum antiviral GS-5734 inhibits both epidemic and zoonotic coronaviruses. Sci Transl Med. 2017;9(396). https://doi.org/10.1126/ scitransImed.aal3653.

109. de Wit E, Feldmann F, Cronin J, Jordan R, Okumura A, Thomas T, et al. Prophylactic and therapeutic remdesivir (GS-5734) treatment in the rhesus macaque model of MERS-CoV infection. Proc Natl Acad Sci U S A. 2020; 117(12):6771-6. https://doi.org/10.1073/pnas.1922083117.

110. Agostini ML, Andres EL, Sims AC, Graham RL, Sheahan TP, Lu X, et al. Coronavirus susceptibility to the antiviral remdesivir (GS-5734) is mediated by the ciral polymerase and the proofreading exoribonuclease. mBio. 2018; 9(2). https://doi.org/10.1128/mBio.00221-18.

111. Muller WE, Maidhof A, Taschner H, Zahn RK. Virazole (1-beta-D-ribofuranosyl1,2,4-triazole-3-carboxamide; a cytostatic agent). Biochem Pharmacol. 1977; 26(11):1071-5. https://doi.org/10.1016/0006-2952(77)90246-5.

112. Page T, Connor JD. The metabolism of ribavirin in erythrocytes and nucleated cells. Int J BioChemiPhysics. 1990;22(4):379-83. https://doi.org/10. 1016/0020-711x(90)90140-x.

113. Graci JD, Cameron CE. Mechanisms of action of ribavirin against distinct viruses. Rev Med Virol. 2006;16(1):37-48. https://doi.org/10.1002/rmv.483.

114. Hultgren C, Milich DR, Weiland O, Sallberg M. The antiviral compound ribavirin modulates the T helper (Th) 1/Th2 subset balance in hepatitis B and C virus-specific immune responses. J Gen Virol. 1998;79(Pt 10):2381-91. https://doi.org/10.1099/0022-1317-79-10-2381.

115. Mosmann TR, Coffman RL. TH1 and TH2 cells: different patterns of lymphokine secretion lead to different functional properties. Annu Rev Immunol. 1989;7: 145-73. https://doi.org/10.1146/annurev.iy.07.040189.001045.

116. Mosmann TR, Sad S. The expanding universe of T-cell subsets: Th1, Th2 and more. Immunol Today. 1996;17(3):138-46. https://doi.org/10.1016/01675699(96)80606-2.

117. Tsai SL, Liaw YF, Chen MH, Huang CY, Kuo GC. Detection of type 2-like Thelper cells in hepatitis $C$ virus infection: implications for hepatitis $C$ virus chronicity. Hepatology. 1997;25(2):449-58. https://doi.org/10.1002/hep. 510250233.

118. Markland W, McQuaid TJ, Jain J, Kwong AD. Broad-spectrum antiviral activity of the IMP dehydrogenase inhibitor VX-497: a comparison with ribavirin and demonstration of antiviral additivity with alpha interferon. Antimicrob Agents Chemother. 2000;44(4):859-66. https://doi.org/10.1128/aac.44.4.859-866.2000.

119. Wang M, Cao R, Zhang L, Yang X, Liu J, Xu M, et al. Remdesivir and chloroquine effectively inhibit the recently emerged novel coronavirus (2019-nCoV) in vitro. Cell Res. 2020;30(3):269-71. https://doi.org/10.1038/ s41422-020-0282-0.

120. Preston SL, Drusano GL, Glue P, Nash J, Gupta SK, McNamara P. Pharmacokinetics and absolute bioavailability of ribavirin in healthy volunteers as determined by stable-isotope methodology. Antimicrob Agents Chemother. 1999;43(10):2451-6. https://doi.org/10.1128/AAC.43.10.2451.

121. Falzarano D, de Wit E, Rasmussen AL, Feldmann F, Okumura A, Scott DP, et al. Treatment with interferon-alpha2b and ribavirin improves outcome in MERS-CoV-infected rhesus macaques. Nat Med. 2013;19(10):1313-7. https:// doi.org/10.1038/nm.3362.

122. Arabi YM, Shalhoub S, Mandourah Y, Al-Hameed F, Al-Omari A, Al Qasim E, et al. Ribavirin and interferon therapy for critically ill patients with Middle East respiratory syndrome: a multicenter observational study. Clin Infect Dis. 2020;70(9):1837-44. https://doi.org/10.1093/cid/ciz544.

123. Booth CM, Matukas LM, Tomlinson GA, Rachlis AR, Rose DB, Dwosh HA et al. Clinical features and short-term outcomes of 144 patients with SARS in the greater Toronto area. JAMA. 2003;289(21):2801-9. https://doi.org/10. 1001/jama.289.21.JOC30885.

124. Lee $N$, Hui D, Wu A, Chan P, Cameron P, Joynt GM, et al. A major outbreak of severe acute respiratory syndrome in Hong Kong. N Engl J Med. 2003; 348(20):1986-94. https://doi.org/10.1056/NEJMoa030685.

125. Huffman JH, Sidwell RW, Khare GP, Witkowski JT, Allen LB, Robins RK. In vitro effect of 1-beta-D-ribofuranosyl-1,2,4-triazole-3-carboxamide (virazole, ICN 1229) on deoxyribonucleic acid and ribonucleic acid viruses. Antimicrob Agents Chemother. 1973;3(2):235-41. https://doi.org/10.1128/aac.3.2.235.

126. Suganuma T, Ishida N. An evaluation of a new antiviral agent "virazole" against influenza virus infections. Tohoku J Exp Med. 1973;110(4):405-6. https://doi.org/10.1620/tjem.110.405.

127. Tan EL, Ooi EE, Lin CY, Tan HC, Ling AE, Lim B, et al. Inhibition of SARS coronavirus infection in vitro with clinically approved antiviral drugs. Emerg Infect Dis. 2004;10(4):581-6. https://doi.org/10.3201/eid1004.030458. 
128. Morgenstern B, Michaelis M, Baer PC, Doerr HW, Cinatl J Jr. Ribavirin and interferon-beta synergistically inhibit SARS-associated coronavirus replication in animal and human cell lines. Biochem Biophys Res Commun. 2005;326(4): 905-8. https://doi.org/10.1016/j.bbrc.2004.11.128.

129. Falzarano D, de Wit E, Martellaro C, Callison J, Munster VJ, Feldmann H. Inhibition of novel beta coronavirus replication by a combination of interferonalpha2b and ribavirin. Sci Rep. 2013;3:1686. https:/doi.org/10.1038/srep01686.

130. Hung IF, Lung KC, Tso EY, Liu R, Chung TW, Chu MY, et al. Triple combination of interferon beta-1b, lopinavir-ritonavir, and ribavirin in the treatment of patients admitted to hospital with COVID-19: an open-label, randomised, phase 2 trial. Lancet. 2020;395(10238):1695-704. https://doi.org/ 10.1016/S0140-6736(20)31042-4.

131. Knowles SR, Phillips EJ, Dresser L, Matukas L. Common adverse events associated with the use of ribavirin for severe acute respiratory syndrome in Canada. Clin Infect Dis. 2003;37(8):1139-42. https://doi.org/10.1086/378304.

132. Sung JJ, Wu A, Joynt GM, Yuen KY, Lee N, Chan PK, et al. Severe acute respiratory syndrome: report of treatment and outcome after a major outbreak. Thorax. 2004;59(5):414-20. https://doi.org/10.1136/thx.2003.014076.

133. Adams R, Christenson J, Petersen F, Beatty P. Pre-emptive use of aerosolized ribavirin in the treatment of asymptomatic pediatric marrow transplant patients testing positive for RSV. Bone Marrow Transplant. 1999;24(6):661-4. https://doi.org/10.1038/sj.bmt.1701959.

134. Stockman LJ, Bellamy R, Garner P. SARS: systematic review of treatment effects. PLoS Med. 2006;3(9):e343. https://doi.org/10.1371/journal.pmed. 0030343.

135. Mantlo E, Bukreyeva N, Maruyama J, Paessler S, Huang C. Antiviral activities of type I interferons to SARS-CoV-2 infection. Antivir Res. 2020;179:104811. https://doi.org/10.1016/j.antiviral.2020.104811.

136. Honda K, Takaoka A, Taniguchi T. Type I interferon gene induction by the interferon regulatory factor family of transcription factors. Immunity. 2006; 25(3):349-60. https://doi.org/10.1016/j.immuni.2006.08.009.

137. Cinatl J Jr, Michaelis M, Scholz M, Doerr HW. Role of interferons in the treatment of severe acute respiratory syndrome. Expert Opin Biol Ther. 2004; 4(6):827-36. https://doi.org/10.1517/14712598.4.6.827.

138. Goodbourn S, Didcock L, Randall RE. Interferons: cell signalling, immune modulation, antiviral response and virus countermeasures. J Gen Virol. 2000; 81(Pt 10):2341-64. https://doi.org/10.1099/0022-1317-81-10-2341.

139. Chawla-Sarkar M, Lindner DJ, Liu YF, Williams BR, Sen GC, Silverman RH, et al. Apoptosis and interferons: role of interferon-stimulated genes as mediators of apoptosis. Apoptosis. 2003;8(3):237-49. https://doi.org/10.1023/ a:1023668705040

140. Balachandran S, Roberts PC, Brown LE, Truong H, Pattnaik AK, Archer DR et al. Essential role for the dsRNA-dependent protein kinase PKR in innate immunity to viral infection. Immunity. 2000;13(1):129-41. https://doi.org/10. 1016/s1074-7613(00)00014-5

141. Abraham N, Stojdl DF, Duncan PI, Methot N, Ishii T, Dube M, et al. Characterization of transgenic mice with targeted disruption of the catalytic domain of the double-stranded RNA-dependent protein kinase, PKR. J Biol Chem. 1999;274(9):5953-62. https://doi.org/10.1074/jbc.274.9.5953.

142. Haller O, Acklin M, Staeheli P. Influenza virus resistance of wild mice: wildtype and mutant mx alleles occur at comparable frequencies. J Interf Res. 1987;7(5):647-56. https://doi.org/10.1089/jir.1987.7.647.

143. Staeheli P. Interferon-induced proteins and the antiviral state. Adv Virus Res. 1990;38:147-200. https://doi.org/10.1016/s0065-3527(08)60862-3.

144. Haller $O$, Staeheli $P$, Kochs $G$. Interferon-induced $m x$ proteins in antiviral host defense. Biochimie. 2007;89(6-7):812-8. https://doi.org/10.1016/j.biochi.2007.04.015.

145. Patterson JB, Thomis DC, Hans SL, Samuel CE. Mechanism of interferon action: double-stranded RNA-specific adenosine deaminase from human cells is inducible by alpha and gamma interferons. Virology. 1995;210(2): 508-11. https://doi.org/10.1006/viro.1995.1370

146. Saunders LR, Barber GN. The dsRNA binding protein family: critical roles, diverse cellular functions. FASEB J. 2003;17(9):961-83. https://doi.org/10. 1096/fj.02-0958rev

147. Samuel CE. Antiviral actions of interferons. Clin Microbiol Rev. 2001;14(4): 778-809. https://doi.org/10.1128/CMR.14.4.778-809.2001.

148. Jayan GC, Casey JL. Increased RNA editing and inhibition of hepatitis delta virus replication by high-level expression of ADAR1 and ADAR2. J Virol. 2002;76(8):3819-27. https://doi.org/10.1128/jvi.76.8.3819-3827.2002.

149. Moll HP, Maier T, Zommer A, Lavoie T, Brostjan C. The differential activity of interferon-alpha subtypes is consistent among distinct target genes and cell types. Cytokine. 2011;53(1):52-9. https://doi.org/10.1016/j.cyto.2010.09.006.
150. Bennett AL, Smith DW, Cummins MJ, Jacoby PA, Cummins JM, Beilharz MW. Low-dose oral interferon alpha as prophylaxis against viral respiratory illness: a double-blind, parallel controlled trial during an influenza pandemic year. Influenza Other Respir Viruses. 2013;7(5):854-62. https://doi.org/10.1111/irv.12094.

151. Yuan J, Zou R, Zeng L, Kou S, Lan J, Li X, et al. The correlation between viral clearance and biochemical outcomes of 94 COVD-19 infected discharged patients. Inflamm Res. 2020;69(6):599-606. https:/doi.org/10.1007/s00011-020-01342-0.

152. Zhou Q, Chen V, Shannon CP, Wei XS, Xiang X, Wang X, et al. Interferona2b treatment for COVID-19. Front Immunol. 2020;11:1061. https://doi.org/ 10.3389/fimmu.2020.01061.

153. Giosuè S, Casarini M, Ameglio F, Alemanno L, Saltini C, Bisetti A. Minimal dose of aerosolized interferon-alpha in human subjects: biological consequences and side-effects. Eur Respir J. 1996;9(1):42-6. https://doi.org/ 10.1183/09031936.96.09010042

154. Maasilta P, Halme M, Mattson K, Cantell K. Pharmacokinetics of inhaled recombinant and natural alpha interferon. Lancet. 1991;337:371. https://doi. org/10.1016/0140-6736(91)91009-J.

155. Hapgood JP, Avenant C, Moliki JM. Glucocorticoid-independent modulation of GR activity: implications for immunotherapy. Pharmacol Ther. 2016;165: 93-113. https://doi.org/10.1016/j.pharmthera.2016.06.002.

156. Meduri GU, Chinn AJ, Leeper KV, Wunderink RG, Tolley E, Winer-Muram HT, et al. Corticosteroid rescue treatment of progressive fibroproliferation in late ARDS. Patterns of response and predictors of outcome. Chest. 1994;105(5): 1516-27. https://doi.org/10.1378/chest.105.5.1516.

157. Jiang $S$, Liu T, Hu Y, Li R, Di X, Jin X, et al. Efficacy and safety of glucocorticoids in the treatment of severe community-acquired pneumonia: a meta-analysis. Medicine. 2019;98(26):e16239. https://doi.org/10.1097/md. 0000000000016239

158. Hu Y, Sun J, Dai Z, Deng H, Li X, Huang Q, et al. Prevalence and severity of corona virus disease 2019 (COVID-19): a systematic review and meta-analysis. J Clin Virol. 2020;127:104371. https://doi.org/10.1016/j.jcv.2020.104371.

159. Arabi YM, Mandourah Y, Al-Hameed F, Sindi AA, Almekhlafi GA, Hussein MA, et al. Corticosteroid therapy for critically ill patients with Middle East respiratory syndrome. Am J Respir Crit Care Med. 2018;197(6):757-67. https://doi.org/10.1164/rccm.201706-11720C.

160. Lansbury LE, Rodrigo C, Leonardi-Bee J, Nguyen-Van-Tam J, Shen Lim W. Corticosteroids as adjunctive therapy in the treatment of influenza: an updated cochrane systematic review and meta-analysis. Crit Care Med. 2020;48(2):e98-e106. https://doi.org/10.1097/ccm.0000000000004093.

161. Han K, Ma H, An X, Su Y, Chen J, Lian Z, et al. Early use of glucocorticoids was a risk factor for critical disease and death from pH1N1 infection. Clin Infect Dis. 2011;53(4):326-33. https://doi.org/10.1093/cid/cir398.

162. Arabi YM, Fowler R, Hayden FG. Critical care management of adults with community-acquired severe respiratory viral infection. Intensive Care Med. 2020;46(2):315-28. https://doi.org/10.1007/s00134-020-05943-5.

163. Wu C, Chen X, Cai Y, Xia J, Zhou X, Xu S, et al. Risk factors associated with acute respiratory distress syndrome and death in patients with coronavirus disease 2019 pneumonia in Wuhan, China. JAMA Intern Med. 2020;180(7): 934-43. https://doi.org/10.1001/jamainternmed.2020.0994.

164. Ye Z, Wang Y, Colunga-Lozano LE, Prasad M, Tangamornsuksan W, Rochwerg B, et al. Efficacy and safety of corticosteroids in COVID-19 based on evidence for COVID-19, other coronavirus infections, influenza, community-acquired pneumonia and acute respiratory distress syndrome: a systematic review and meta-analysis. CMAJ. 2020;192(27):E756-67. https:// doi.org/10.1503/cmaj.200645.

165. Zha L, Li S, Pan L, Tefsen B, Li Y, French N, et al. Corticosteroid treatment of patients with coronavirus disease 2019 (COVID-19). Med J Aust. 2020;212(9): 416-20. https://doi.org/10.5694/mja2.50577.

166. Li X, Xu S, Yu M, Wang K, Tao Y, Zhou Y, et al. Risk factors for severity and mortality in adult COVID-19 inpatients in Wuhan. J Allergy Clin Immunol. 2020;146(1):110-8. https://doi.org/10.1016/j.jaci.2020.04.006.

167. Li H, Chen C, Hu F, Wang J, Zhao Q, Gale RP, et al. Impact of corticosteroid therapy on outcomes of persons with SARS-CoV-2, SARS-CoV, or MERS-CoV infection: a systematic review and meta-analysis. Leukemia. 2020;34(6):150311. https://doi.org/10.1038/s41375-020-0848-3.

168. Lamontagne F, Agoritsas T, Macdonald H, Leo YS, Diaz J, Agarwal A, et al. A living WHO guideline on drugs for covid-19. BMJ. 2020;370:m3379. https:// doi.org/10.1136/bmj.m3379.

169. Halpin DMG, Singh D, Hadfield RM. Inhaled corticosteroids and COVID-19: a systematic review and clinical perspective. Eur Respir J. 2020:55(5):2001009. https://doi.org/10.1183/13993003.01009-2020. 
170. Huang C, Wang Y, Li X, Ren L, Zhao J, Hu Y, et al. Clinical features of patients infected with 2019 novel coronavirus in Wuhan, China. Lancet. 2020;395(10223):497-506. https://doi.org/10.1016/s0140-6736(20)30183-5.

171. Xu Z, Shi L, Wang Y, Zhang J, Huang L, Zhang C, et al. Pathological findings of COVID-19 associated with acute respiratory distress syndrome. Lancet Respir Med. 2020;8(4):420-2. https://doi.org/10.1016/s2213-2600(20)30076-X.

172. Liu B, Li M, Zhou Z, Guan X, Xiang Y. Can we use interleukin-6 (IL-6) blockade for coronavirus disease 2019 (COVID-19)-induced cytokine release syndrome (CRS)? J Autoimmun. 2020;111:102452. https://doi.org/10.1016/j. jaut.2020.102452

173. Pedersen SF, Ho YC. SARS-CoV-2: a storm is raging. J Clin Invest. 2020;130(5): 2202-5. https://doi.org/10.1172/jci137647.

174. Chen G, Wu D, Guo W, Cao Y, Huang D, Wang H, et al. Clinical and immunological features of severe and moderate coronavirus disease 2019. J Clin Invest. 2020;130(5):2620-9. https://doi.org/10.1172/jci137244.

175. Cunningham L, Kimber I, Basketter DA, McFadden JP. Why judiciously timed anti-IL 6 therapy may be of benefit in severe COVID-19 infection. Autoimmun Rev. 2020;19(7):102563. https://doi.org/10.1016/j.autrev.2020. 102563.

176. Tanaka T, Narazaki M, Kishimoto T. Immunotherapeutic implications of IL-6 blockade for cytokine storm. Immunotherapy. 2016;8(8):959-70. https://doi. org/10.2217/imt-2016-0020.

177. DeDiego ML, Nieto-Torres JL, Regla-Nava JA, Jimenez-Guardeño JM, Fernandez-Delgado R, Fett C, et al. Inhibition of NF-kB-mediated inflammation in severe acute respiratory syndrome coronavirus-infected mice increases survival. J Virol. 2014;88(2):913-24. https://doi.org/10.1128/jvi. 02576-13.

178. McGonagle D, Sharif K, O'Regan A, Bridgewood C. The role of cytokines including Interleukin-6 in COVID-19 induced pneumonia and macrophage activation syndrome-like disease. Autoimmun Rev. 2020;19(6):102537. https://doi.org/10.1016/j.autrev.2020.102537.

179. Choy EH, De Benedetti F, Takeuchi T, Hashizume M, John MR, Kishimoto T. Translating IL-6 biology into effective treatments. Nat Rev Rheumatol. 2020; 16(6):335-45. https://doi.org/10.1038/s41584-020-0419-z.

180. Alzghari SK, Acuña VS. Supportive treatment with Tocilizumab for COVID-19: a systematic review. J Clin Virol. 2020;127:104380. https://doi.org/10.1016/j. jcv.2020.104380.

181. Xu X, Han M, Li T, Sun W, Wang D, Fu B, et al. Effective treatment of severe COVID-19 patients with tocilizumab. Proc Natl Acad Sci U S A. 2020;117(20): 10970-5. https://doi.org/10.1073/pnas.2005615117.

182. Klopfenstein T, Zayet S, Lohse A, Balblanc JC, Badie J, Royer PY, et al. Tocilizumab therapy reduced intensive care unit admissions and/or mortality in COVID-19 patients. Med Mal Infect. 2020;50(5):397-400. https:// doi.org/10.1016/j.medmal.2020.05.001.

183. Hassoun A, Thottacherry ED, Muklewicz J, Aziz QU, Edwards J. Utilizing tocilizumab for the treatment of cytokine release syndrome in COVID-19. J Clin Virol. 2020;128:104443. https://doi.org/10.1016/j.jcv.2020.104443.

184. Alattar R, Ibrahim TBH, Shaar SH, Abdalla S, Shukri K, Daghfal JN, et al. Tocilizumab for the treatment of severe coronavirus disease 2019. J Med Virol. 2020. https://doi.org/10.1002/jmv.25964.

185. Agarwal S, June CH. Harnessing CAR T-cell insights to develop treatments for hyperinflammatory responses in patients with COVID-19. Cancer Discov. 2020;10(6):775-8. https://doi.org/10.1158/2159-8290.CD-20-0473.

186. Toniati P, Piva S, Cattalini M, Garrafa E, Regola F, Castelli F, et al. Tocilizumab for the treatment of severe COVID-19 pneumonia with hyperinflammatory syndrome and acute respiratory failure: a single center study of 100 patients in Brescia, Italy. Autoimmun Rev. 2020;19(7):102568. https://doi.org/10.1016/j. autrev.2020.102568.

187. Antwi-Amoabeng D, Kanji Z, Ford B, Beutler BD, Riddle MS, Siddiqui F. Clinical outcomes in COVID-19 patients treated with Tocilizumab: an individual patient data systematic review. J Med Virol. 2020. https://doi.org/ 10.1002/jmv.26038.

188. Quartuccio L, Sonaglia A, McGonagle D, Fabris M, Peghin M, Pecori D, et al. Profiling COVID-19 pneumonia progressing into the cytokine storm syndrome: results from a single Italian Centre study on tocilizumab versus standard of care. J Clin Virol. 2020;129:104444. https://doi.org/10.1016/j.jcv. 2020.104444.

189. Capra R, De Rossi N, Mattioli F, Romanelli G, Scarpazza C, Sormani MP, et al. Impact of low dose tocilizumab on mortality rate in patients with COVID-19 related pneumonia. Eur J Intern Med. 2020;76:31-5. https://doi.org/10.1016/j. ejim.2020.05.009.
190. Radbel J, Narayanan N, Bhatt PJ. Use of Tocilizumab for COVID-19-induced cytokine release syndrome: a cautionary case report. Chest. 2020;158(1):e159. https://doi.org/10.1016/j.chest.2020.04.024.

191. Schwartz DM, Bonelli M, Gadina M, O'Shea JJ. Type I/II cytokines, JAKs, and new strategies for treating autoimmune diseases. Nat Rev Rheumatol. 2016; 12(1):25-36. https://doi.org/10.1038/nrrheum.2015.167.

192. Müller M, Briscoe J, Laxton C, Guschin D, Ziemiecki A, Silvennoinen O, et al. The protein tyrosine kinase JAK1 complements defects in interferon-alpha/ beta and -gamma signal transduction. Nature. 1993;366(6451):129-35. https://doi.org/10.1038/366129a0.

193. Ghoreschi K, Laurence A, O'Shea JJ. Janus kinases in immune cell signaling. Immunol Rev. 2009;228(1):273-87. https://doi.org/10.1111/j.1600-065X.2008.00754.x.

194. Spinelli FR, Conti F, Gadina M. HiJAKing SARS-CoV-2? The potential role of JAK inhibitors in the management of COVID-19. Sci Immunol. 2020;5(47): eabc5367. https://doi.org/10.1126/sciimmunol.abc5367.

195. Schwartz DM, Kanno Y, Villarino A, Ward M, Gadina M, O'Shea JJ. JAK inhibition as a therapeutic strategy for immune and inflammatory diseases. Nat Rev Drug Discov. 2017;16(12):843-62. https://doi.org/10.1038/nrd.2017.201.

196. Zhou P, Yang XL, Wang XG, Hu B, Zhang L, Zhang W, et al. A pneumonia outbreak associated with a new coronavirus of probable bat origin. Nature. 2020:579(7798):270-3. https://doi.org/10.1038/s41586-020-2012-7.

197. Walls AC, Park YJ, Tortorici MA, Wall A, McGuire AT, Veesler D. Structure, function, and antigenicity of the SARS-CoV-2 spike glycoprotein. Cell. 2020; 181(2):281-92.e6. https://doi.org/10.1016/j.cell.2020.02.058.

198. Hoffmann M, Kleine-Weber H, Schroeder S, Krüger N, Herrler T, Erichsen S, et al. SARS-CoV-2 cell entry depends on ACE2 and TMPRSS2 and is blocked by a clinically proven protease inhibitor. Cell. 2020;181(2):271-80.e8. https:// doi.org/10.1016/j.cell.2020.02.052.

199. Cheng H, Wang Y, Wang GQ. Organ-protective effect of angiotensinconverting enzyme 2 and its effect on the prognosis of COVID-19. J Med Virol. 2020;92(7):726-30. https://doi.org/10.1002/jmv.25785.

200. Wong CK, Lam CW, Wu AK, Ip WK, Lee NL, Chan IH, et al. Plasma inflammatory cytokines and chemokines in severe acute respiratory syndrome. Clin Exp Immunol. 2004;136(1):95-103. https://doi.org/10.1111/j. 1365-2249.2004.02415.x.

201. Richardson P, Griffin I, Tucker C, Smith D, Oechsle O, Phelan A, et al. Baricitinib as potential treatment for 2019-nCoV acute respiratory disease. Lancet. 2020:395(10223):e30-e1. https://doi.org/10.1016/s01406736(20)30304-4.

202. Taylor PC. Clinical efficacy of launched JAK inhibitors in rheumatoid arthritis. Rheumatology (Oxford). 2019;58(Suppl 1):i17-26. https://doi.org/10.1093/ rheumatology/key225.

203. Cantini F, Niccoli L, Matarrese D, Nicastri E, Stobbione P, Goletti D. Baricitinib therapy in COVID-19: a pilot study on safety and clinical impact. J Inf Secur. 2020;81(2):318-56. https://doi.org/10.1016/j.jinf.2020.04.017.

204. Praveen D, Puvvada RC, VA M. Janus kinase inhibitor baricitinib is not an ideal option for management of COVID-19. Int J Antimicrob Agents. 2020; 55(5):105967. https://doi.org/10.1016/j.jjantimicag.2020.105967.

205. Hadjadj J, Yatim N, Barnabei L, Corneau A, Boussier J, Pere H, et al. Impaired type I interferon activity and inflammatory responses in severe COVID-19 patients. Science. 2020;369(6504):718-24. https://doi.org/10.1126/science. abc6027.

206. Bloch EM, Shoham S, Casadevall A, Sachais BS, Shaz B, Winters JL, et al. Deployment of convalescent plasma for the prevention and treatment of COVID-19. J Clin Invest. 2020;130(6):2757-65. https://doi.org/10.1172/jci138745.

207. Lünemann JD, Nimmerjahn F, Dalakas MC. Intravenous immunoglobulin in neurology--mode of action and clinical efficacy. Nat Rev Neurol. 2015;11(2): 80-9. https://doi.org/10.1038/nrneurol.2014.253.

208. Long QX, Liu BZ, Deng HJ, Wu GC, Deng K, Chen YK, et al. Antibody responses to SARS-CoV-2 in patients with COVID-19. Nat Med. 2020;26(6): 845-8. https://doi.org/10.1038/s41591-020-0897-1.

209. Zheng S, Fan J, Yu F, Feng B, Lou B, Zou Q, et al. Viral load dynamics and disease severity in patients infected with SARS-CoV-2 in Zhejiang province, China, January-march 2020: retrospective cohort study. BMJ. 2020;369: m1443. https://doi.org/10.1136/bmj.m1443.

210. Chandrashekar A, Liu J, Martinot AJ, McMahan K, Mercado NB, Peter L, et al. SARS-CoV-2 infection protects against rechallenge in rhesus macaques. Science. 2020;369(6505):812-7. https://doi.org/10.1126/science.abc4776.

211. van Griensven J, Gallian P, de Lamballerie X. Convalescent plasma and the dose of Ebola virus antibodies. N Engl J Med. 2017;376(13):1297. https://doi. org/10.1056/NEJMc1700090. 
212. Zhou B, Zhong N, Guan Y. Treatment with convalescent plasma for influenza a (H5N1) infection. N Engl J Med. 2007;357(14):1450-1. https://doi. org/10.1056/NEJMc070359.

213. Yu H, Gao Z, Feng Z, Shu Y, Xiang N, Zhou L, et al. Clinical characteristics of 26 human cases of highly pathogenic avian influenza a (H5N1) virus infection in China. PLoS One. 2008;3(8):e2985. https://doi.org/10.1371/ journal.pone.0002985.

214. Wu XX, Gao HN, Wu HB, Peng XM, Ou HL, Li LJ. Successful treatment of avian-origin influenza a (H7N9) infection using convalescent plasma. Int J Infect Dis. 2015;41:3-5. https://doi.org/10.1016/j.jijid.2015.10.009.

215. Kong LK, Zhou BP. Successful treatment of avian influenza with convalescent plasma. Hong Kong Med J. 2006;12(6):489.

216. Hung IF, To KK, Lee CK, Lee KL, Chan K, Yan WW, et al. Convalescent plasma treatment reduced mortality in patients with severe pandemic influenza a (H1N1) 2009 virus infection. Clin Infect Dis. 2011;52(4):447-56. https://doi. org/10.1093/cid/ciq106.

217. Soo YO, Cheng Y, Wong R, Hui DS, Lee CK, Tsang KK, et al. Retrospective comparison of convalescent plasma with continuing high-dose methylprednisolone treatment in SARS patients. Clin Microbiol Infect. 2004; 10(7):676-8. https://doi.org/10.1111/j.1469-0691.2004.00956.x.

218. Mair-Jenkins J, Saavedra-Campos M, Baillie JK, Cleary P, Khaw FM, Lim WS, et al. The effectiveness of convalescent plasma and hyperimmune immunoglobulin for the treatment of severe acute respiratory infections of viral etiology: a systematic review and exploratory meta-analysis. J Infect Dis. 2015;211(1):80-90. https://doi.org/10.1093/infdis/jiu396.

219. Shen C, Wang Z, Zhao F, Yang Y, Li J, Yuan J, et al. Treatment of 5 critically ill patients with COVID-19 with convalescent plasma. JAMA. 2020;323(16): 1582-9. https://doi.org/10.1001/jama.2020.4783.

220. Duan K, Liu B, Li C, Zhang H, Yu T, Qu J, et al. Effectiveness of convalescent plasma therapy in severe COVID-19 patients. Proc Natl Acad Sci U S A. 2020; 117(17):9490-6. https://doi.org/10.1073/pnas.2004168117.

221. Tanne JH. Covid-19: FDA approves use of convalescent plasma to treat critically ill patients. BMJ. 2020;368:m1256. https://doi.org/10.1136/bmj. m1256.

222. Fleming $A B$, Raabe V. Current studies of convalescent plasma therapy for COVID-19 may underestimate risk of antibody-dependent enhancement. J Clin Virol. 2020;127:104388. https://doi.org/10.1016/j.jcv.2020.104388.

223. Valk SJ, Piechotta V, Chai KL, Doree C, Monsef I, Wood EM, et al. Convalescent plasma or hyperimmune immunoglobulin for people with COVID-19: a rapid review. Cochrane Database Syst Rev. 2020;5:Cd013600. https://doi.org/10.1002/14651858.Cd013600.

224. Sullivan HC, Roback JD. Convalescent plasma: therapeutic hope or hopeless strategy in the SARS-CoV-2 pandemic. Transfus Med Rev. 2020;34(3):145-50. https://doi.org/10.1016/j.tmrv.2020.04.001.

225. Smolen JS, Landewé R, Breedveld FC, Buch M, Burmester G, Dougados M, et al. EULAR recommendations for the management of rheumatoid arthritis with synthetic and biological disease-modifying antirheumatic drugs: 2013 update. Ann Rheum Dis. 2014;73(3):492-509. https://doi.org/10.1136/ annrheumdis-2013-204573.

226. Fanouriakis A, Kostopoulou M, Alunno A, Aringer M, Bajema I, Boletis JN, et al. 2019 update of the EULAR recommendations for the management of systemic lupus erythematosus. Ann Rheum Dis. 2019;78(6):736-45. https:// doi.org/10.1136/annrheumdis-2019-215089.

227. Tektonidou MG, Andreoli L, Limper M, Amoura Z, Cervera R, CostedoatChalumeau $\mathrm{N}$, et al. EULAR recommendations for the management of antiphospholipid syndrome in adults. Ann Rheum Dis. 2019;78(10):1296304. https://doi.org/10.1136/annrheumdis-2019-215213.

228. Ohkuma S, Poole B. Fluorescence probe measurement of the intralysosomal $\mathrm{pH}$ in living cells and the perturbation of $\mathrm{pH}$ by various agents. Proc Natl Acad Sci U S A. 1978;75(7):3327-31. https://doi.org/10.1073/pnas.75.7.3327.

229. Lotteau $V$, Teyton L, Peleraux A, Nilsson T, Karlsson L, Schmid SL, et al. Intracellular transport of class II MHC molecules directed by invariant chain. Nature. 1990;348(6302):600-5. https://doi.org/10.1038/348600a0.

230. Ziegler HK, Unanue ER. Decrease in macrophage antigen catabolism caused by ammonia and chloroquine is associated with inhibition of antigen presentation to T cells. Proc Natl Acad Sci U S A. 1982;79(1):175-8. https:// doi.org/10.1073/pnas.79.1.175.

231. Rutz M, Metzger J, Gellert T, Luppa P, Lipford GB, Wagner H, et al. Toll-like receptor 9 binds single-stranded $\mathrm{CpG}$-DNA in a sequence- and $\mathrm{pH}$ dependent manner. Eur J Immunol. 2004;34(9):2541-50. https://doi.org/10. 1002/eji.200425218.
232. Ewald SE, Lee BL, Lau L, Wickliffe KE, Shi GP, Chapman HA, et al. The ectodomain of toll-like receptor 9 is cleaved to generate a functional receptor. Nature. 2008;456(7222):658-62. https://doi.org/10.1038/ nature07405.

233. Schrezenmeier E, Dörner T. Mechanisms of action of hydroxychloroquine and chloroquine: implications for rheumatology. Nat Rev Rheumatol. 2020; 16(3):155-66. https://doi.org/10.1038/s41584-020-0372-x.

234. van den Borne BE, Dijkmans BA, de Rooij HH, le Cessie S, Verweij CL. Chloroquine and hydroxychloroquine equally affect tumor necrosis factoralpha, interleukin 6, and interferon-gamma production by peripheral blood mononuclear cells. J Rheumatol. 1997;24(1):55-60.

235. Takano T, Katoh Y, Doki T, Hohdatsu T. Effect of chloroquine on feline infectious peritonitis virus infection in vitro and in vivo. Antivir Res. 2013; 99(2):100-7. https://doi.org/10.1016/j.antiviral.2013.04.016.

236. Sperber K, Quraishi H, Kalb TH, Panja A, Stecher V, Mayer L. Selective regulation of cytokine secretion by hydroxychloroquine: inhibition of interleukin 1 alpha (IL-1-alpha) and IL-6 in human monocytes and T cells. J Rheumatol. 1993;20(5):803-8.

237. Khan M, Santhosh SR, Tiwari M, Lakshmana Rao PV, Parida M. Assessment of in vitro prophylactic and therapeutic efficacy of chloroquine against Chikungunya virus in vero cells. J Med Virol. 2010;82(5):817-24. https://doi. org/10.1002/jmv.21663.

238. Savarino A, Di Trani L, Donatelli I, Cauda R, Cassone A. New insights into the antiviral effects of chloroquine. Lancet Infect Dis. 2006;6(2):67-9. https://doi. org/10.1016/s1473-3099(06)70361-9.

239. Hashem AM, Alghamdi BS, Algaissi AA, Alshehri FS, Bukhari A, Alfaleh MA, et al. Therapeutic use of chloroquine and hydroxychloroquine in COVID-19 and other viral infections: a narrative review. Travel Med Infect Dis. 2020:35: 101735. https://doi.org/10.1016/j.tmaid.2020.101735.

240. Sperber K, Chiang G, Chen H, Ross W, Chusid E, Gonchar M, et al. Comparison of hydroxychloroquine with zidovudine in asymptomatic patients infected with human immunodeficiency virus type 1. Clin Ther. 1997;19(5):913-23. https://doi.org/10.1016/s0149-2918(97)80045-8.

241. Sperber K, Louie M, Kraus T, Proner J, Sapira E, Lin S, et al. Hydroxychloroquine treatment of patients with human immunodeficiency virus type 1. Clin Ther. 1995;17(4):622-36. https:/doi.org/10.1016/0149-2918(95)80039-5.

242. Li C, Zhu X, Ji X, Quanquin N, Deng YQ, Tian M, et al. Chloroquine, a FDAapproved drug, prevents Zika virus infection and its associated congenital microcephaly in mice. EBioMedicine. 2017;24:189-94. https://doi.org/10. 1016/j.ebiom.2017.09.034.

243. Ooi EE, Chew JS, Loh JP, Chua RC. In vitro inhibition of human influenza a virus replication by chloroquine. Virol J. 2006;3:39. https://doi.org/10.1186/ $1743-422 x-3-39$

244. Keyaerts E, Vijgen L, Maes P, Neyts J, Van Ranst M. In vitro inhibition of severe acute respiratory syndrome coronavirus by chloroquine. Biochem Biophys Res Commun. 2004;323(1):264-8. https://doi.org/10.1016/j.bbrc.2004.08.085.

245. Barnard DL, Day CW, Bailey K, Heiner M, Montgomery R, Lauridsen L, et al. Evaluation of immunomodulators, interferons and known in vitro SARS-coV inhibitors for inhibition of SARS-coV replication in BALB/C mice. Antivir Chem Chemother. 2006;17(5):275-84. https://doi.org/10.1177/095632020601700505.

246. Yao X, Ye F, Zhang M, Cui C, Huang B, Niu P, et al. In vitro antiviral activity and projection of optimized dosing design of hydroxychloroquine for the treatment of severe acute respiratory syndrome coronavirus 2 (SARS-CoV-2). Clin Infect Dis. 2020;71(15):732-9. https://doi.org/10.1093/cid/ciaa237.

247. Gautret P, Lagier JC, Parola P, Hoang VT, Meddeb L, Mailhe M, et al. Hydroxychloroquine and azithromycin as a treatment of COVID-19: results of an open-label non-randomized clinical trial. Int J Antimicrob Agents. 2020:105949. https://doi.org/10.1016/j.ijantimicag.2020.105949.

248. Molina JM, Delaugerre C, Le Goff J, Mela-Lima B, Ponscarme D, Goldwirt L, et al. No evidence of rapid antiviral clearance or clinical benefit with the combination of hydroxychloroquine and azithromycin in patients with severe COVID-19 infection. Med Mal Infect. 2020;50(4):384. https://doi.org/10. 1016/j.medmal.2020.03.006

249. Chowdhury MS, Rathod J, Gernsheimer J. A rapid systematic review of clinical trials utilizing chloroquine and hydroxychloroquine as a treatment for COVID19. Acad Emerg Med. 2020;27(6):493-504. https://doi.org/10.1111/acem.14005.

250. Mahévas M, Tran VT, Roumier M, Chabrol A, Paule R, Guillaud C, et al. Clinical efficacy of hydroxychloroquine in patients with covid-19 pneumonia who require oxygen: observational comparative study using routine care data. BMJ (Clinical research ed). 2020;369:m1844. https://doi.org/10.1136/ bmj.m1844. 
251. Geleris J, Sun Y, Platt J, Zucker J, Baldwin M, Hripcsak G, et al. Observational study of hydroxychloroquine in hospitalized patients with COVID-19. N Engl J Med. 2020;382(25):2411-8. https://doi.org/10.1056/NEJMoa2012410.

252. Rosenberg ES, Dufort EM, Udo T, Wilberschied LA, Kumar J, Tesoriero J, et al. Association of treatment with hydroxychloroquine or azithromycin with inhospital mortality in patients with COVID-19 in New York state. JAMA. 2020; 323(24):2493-502. https://doi.org/10.1001/jama.2020.8630.

253. Gevers S, Kwa MSG, Wijnans E, van Nieuwkoop C. Safety considerations of chloroquine and hydroxychloroquine in treatment of COVID-19. Clin Microbiol Infect. 2020;26(9):1276-7. https://doi.org/10.1016/j.cmi.2020.05.006.

254. Nguyen KB, Salazar-Mather TP, Dalod MY, Van Deusen JB, Wei XQ, Liew FY, et al. Coordinated and distinct roles for IFN-alpha beta, IL-12, and IL-15 regulation of NK cell responses to viral infection. J Immunol. 2002;169(8): 4279-87. https://doi.org/10.4049/jimmunol.169.8.4279.

255. Swann JB, Hayakawa Y, Zerafa N, Sheehan KC, Scott B, Schreiber RD, et al. Type I IFN contributes to NK cell homeostasis, activation, and antitumor function. J Immunol. 2007;178(12):7540-9. https://doi.org/10.4049/jimmunol.178.12.7540.

256. Spadaro F, Lapenta C, Donati S, Abalsamo L, Barnaba V, Belardelli F, et al. IFN-a enhances cross-presentation in human dendritic cells by modulating antigen survival, endocytic routing, and processing. Blood. 2012;119(6): 1407-17. https://doi.org/10.1182/blood-2011-06-363564.

257. Le Bon A, Thompson C, Kamphuis E, Durand V, Rossmann C, Kalinke U, et al. Cutting edge: enhancement of antibody responses through direct stimulation of B and T cells by type I IFN. J Immunol. 2006;176(4):2074-8. https://doi.org/10.4049/jimmunol.176.4.2074.

258. Le Bon A, Durand V, Kamphuis E, Thompson C, Bulfone-Paus S, Rossmann C, et al. Direct stimulation of T cells by type I IFN enhances the CD8+ T cell response during cross-priming. J Immunol. 2006;176(8):4682-9. https://doi. org/10.4049/jimmunol.176.8.4682

259. Rehermann B, Bertoletti A. Immunological aspects of antiviral therapy of chronic hepatitis B virus and hepatitis $C$ virus infections. Hepatology (Baltimore, Md). 2015;61(2):712-21. https://doi.org/10.1002/hep.27323.

260. Loutfy MR, Blatt LM, Siminovitch KA, Ward S, Wolff B, Lho H, et al. Interferon alfacon-1 plus corticosteroids in severe acute respiratory syndrome: a preliminary study. JAMA. 2003;290(24):3222-8. https://doi.org/10.1001/jama.290.24.3222.

261. Prokunina-Olsson L, Alphonse N, Dickenson RE, Durbin JE, Glenn JS, Hartmann $\mathrm{R}$, et al. COVID-19 and emerging viral infections: the case for interferon lambda. J Exp Med. 2020;217(5). https://doi.org/10.1084/jem.20200653.

262. Andreakos E, Tsiodras S. COVID-19: lambda interferon against viral load and hyperinflammation. EMBO Mol Med. 2020;12(6):e12465. https://doi.org/10. 15252/emmm.202012465.

263. Simon HU, Späth PJ. IVIG--mechanisms of action. Allergy. 2003;58(7):543-52. https://doi.org/10.1034/j.1398-9995.2003.00239.x.

264. Vani J, Elluru S, Negi VS, Lacroix-Desmazes S, Kazatchkine MD, Bayry J, et al. Role of natural antibodies in immune homeostasis: IVlg perspective. Autoimmun Rev. 2008;7(6):440-4. https://doi.org/10.1016/j.autrev.2008.04.011.

265. Galeotti C, Kaveri SV, Bayry J. IVIG-mediated effector functions in autoimmune and inflammatory diseases. Int Immunol. 2017;29(11):491-8. https://doi.org/10.1093/intimm/dxx039.

266. Ho JC, Wu AY, Lam B, Ooi GC, Khong PL, Ho PL, et al. Pentaglobin in steroid-resistant severe acute respiratory syndrome. Int J Tuberc Lung Dis. 2004;8(10):1173-9.

267. Chen CY, Lee CH, Liu CY, Wang JH, Wang LM, Perng RP. Clinical features and outcomes of severe acute respiratory syndrome and predictive factors for acute respiratory distress syndrome. J Chin Med Assoc. 2005;68(1):4-10. https://doi.org/10.1016/s1726-4901(09)70124-8.

268. Díez JM, Romero C, Gajardo R. Currently available intravenous immunoglobulin contains antibodies reacting against severe acute respiratory syndrome coronavirus 2 antigens. Immunotherapy. 2020;12(8): 571-6. https://doi.org/10.2217/imt-2020-0095.

269. Xie Y, Cao S, Dong H, Li Q, Chen E, Zhang W, et al. Effect of regular intravenous immunoglobulin therapy on prognosis of severe pneumonia in patients with COVID-19. J Inf Secur. 2020;81(2):318-56. https://doi.org/10. 1016/j.jinf.2020.03.044

270. Shi H, Zhou C, He P, Huang S, Duan Y, Wang X, et al. Successful treatment with plasma exchange followed by intravenous immunoglobulin in a critically ill patient with COVID-19. Int J Antimicrob Agents. 2020;56(2): 105974. https://doi.org/10.1016/j.ijantimicag.2020.105974.

271. Mohtadi N, Ghaysouri A, Shirazi S, Ansari S, Shafiee E, Bastani E, et al. Recovery of severely ill COVID-19 patients by intravenous immunoglobulin (IVIG) treatment: a case series. Virology. 2020;548:1-5. https://doi.org/10.1016/j.virol.2020.05.006.
272. Xiao K, Hou F, Huang X, Li B, Qian ZR, Xie L. Mesenchymal stem cells: current clinical progress in ARDS and COVID-19. Stem Cell Res Ther. 2020; 11(1):305. https://doi.org/10.1186/s13287-020-01804-6.

273. Golchin A, Farahany TZ. Biological products: cellular therapy and FDA approved products. Stem Cell Rev Rep. 2019;15(2):166-75. https://doi.org/10. 1007/s12015-018-9866-1.

274. Rogers C, Harman R, Bunnell B, Schreiber M, Xiang C, Wang F, et al. Rationale for the clinical use of adipose-derived mesenchymal stem cells for COVD-19 patients. J Transl Med. 2020;18(1):203. https:/doi.org/10.1186/s12967-020-02380-2.

275. Golchin A, Farahany TZ, Khojasteh A, Soleimanifar F, Ardeshirylajimi A. The clinical trials of mesenchymal stem cell therapy in skin diseases: an update and concise review. Curr Stem Cell Res Ther. 2019;14(1):22-33. https://doi. org/10.2174/1574888X13666180913123424.

276. Zhu Z, Lu Z, Xu T, Chen C, Yang G, Zha T, et al. Arbidol monotherapy is superior to lopinavir/ritonavir in treating COVID-19. J Inf Secur. 2020;81(1): e21-3. https://doi.org/10.1016/j.jinf.2020.03.060.

277. Zhao K, Liu Q. The clinical application of mesenchymal stromal cells in hematopoietic stem cell transplantation. J Hematol Oncol. 2016;9(1):46. https://doi.org/10.1186/s13045-016-0276-z.

278. Mannon PJ. Remestemcel-L: human mesenchymal stem cells as an emerging therapy for Crohn's disease. Expert Opin Biol Ther. 2011;11(9): 1249-56. https://doi.org/10.1517/14712598.2011.602967.

279. Kebriaei P, Hayes J, Daly A, Uberti J, Marks DI, Soiffer R, et al. A phase 3 randomized study of Remestemcel-L versus placebo added to second-line therapy in patients with steroid-refractory acute graft-versus-host disease. Biol Blood Marrow Transplant. 2020;26(5):835-44. https://doi.org/10.1016/j. bbmt.2019.08.029.

280. Leng Z, Zhu R, Hou W, Feng Y, Yang Y, Han Q, et al. Transplantation of ACE2 mesenchymal stem cells improves the outcome of patients with COVID-19 pneumonia. Aging Dis. 2020;11(2):216-28. https://doi.org/10. 14336/ad.2020.0228.

281. Lau JT, Leung PC, Wong EL, Fong C, Cheng KF, Zhang SC, et al. The use of an herbal formula by hospital care workers during the severe acute respiratory syndrome epidemic in Hong Kong to prevent severe acute respiratory syndrome transmission, relieve influenza-related symptoms, and improve quality of life: a prospective cohort study. J Altern Complement Med. 2005;11(1):49-55. https://doi.org/10.1089/acm.2005.11.49.

282. Gao J, Li J, Shao X, Jin Y, Lü XW, Ge JF, et al. Antiinflammatory and immunoregulatory effects of total glucosides of Yupingfeng powder. Chin Med J. 2009;122(14):1636-41.

283. Luo H, Tang QL, Shang YX, Liang SB, Yang M, Robinson N, et al. Can chinese medicine be used for prevention of corona Vvrus disease 2019 (COVID-19)? A review of historical classics, research evidence and current prevention programs. Chin J Integr Med. 2020;26(4):243-50. https://doi.org/ 10.1007/s11655-020-3192-6.

284. Dai W, Chen J, Lu P, Gao Y, Chen L, Liu X, et al. Pathway pattern-based prediction of active drug components and gene targets from H1N1 influenza's treatment with maxingshigan-yinqiaosan formula. Mol BioSyst. 2013;9(3):375-85. https://doi.org/10.1039/c2mb25372k.

285. Wang C, Cao B, Liu QQ, Zou ZQ, Liang ZA, Gu L, et al. Oseltamivir compared with the Chinese traditional therapy maxingshigan-yinqiaosan in the treatment of H1N1 influenza: a randomized trial. Ann Intern Med. 2011; 155(4):217-25. https://doi.org/10.7326/0003-4819-155-4-201108160-00005.

286. Cohen J. Vaccine designers take first shots at COVID-19. Science. 2020; 368(6486):14-6. https://doi.org/10.1126/science.368.6486.14.

287. Ussher JE, Le Gros G, Quiñones-Mateu ME, Gulab SA, Yiannoutsos M. The case for New Zealand to have its own COVID-19 vaccine programme. N Z Med J. 2020;133(1513):112-5.

288. Gea-Mallorquí E, Compeer EB. SARS-CoV-2 vaccine - think globally, act locally. Nat Rev Immunol. 2020;20:590. https://doi.org/10.1038/s41577-02000422-w.

289. Shi Y, Wang N, Zou QM. Progress and challenge of vaccine development against 2019 novel coronavirus (2019-nCoV). Zhonghua Yu Fang Yi Xue Za Zhi. 2020;54(6):614-9. https://doi.org/10.3760/cma.j.cn112150-2020031700366.

290. Armanini D, Kuhnle U, Strasser T, Dorr H, Butenandt I, Weber PC, et al. Aldosterone-receptor deficiency in pseudohypoaldosteronism. N Engl J Med. 1985;313(19):1178-81. https://doi.org/10.1056/nejm198511073131902.

291. Schlake T, Thess A, Fotin-Mleczek M, Kallen KJ. Developing mRNA-vaccine technologies. RNA Biol. 2012;9(11):1319-30. https://doi.org/10.4161/rna. 22269 . 
292. lavarone C, O'Hagan DT, Yu D, Delahaye NF, Ulmer JB. Mechanism of action of mRNA-based vaccines. Expert Rev Vaccines. 2017;16(9):871-81. https://doi. org/10.1080/14760584.2017.1355245.

293. Kormann MS, Hasenpusch G, Aneja MK, Nica G, Flemmer AW, Herber-Jonat $\mathrm{S}$, et al. Expression of therapeutic proteins after delivery of chemically modified mRNA in mice. Nat Biotechnol. 2011;29(2):154-7. https://doi.org/ 10.1038/nbt.1733.

294. Heiser A, Coleman D, Dannull J, Yancey D, Maurice MA, Lallas CD, et al. Autologous dendritic cells transfected with prostate-specific antigen RNA stimulate CTL responses against metastatic prostate tumors. J Clin Invest. 2002;109(3):409-17. https://doi.org/10.1172/jci14364.

295. Bahl K, Senn JJ, Yuzhakov O, Bulychev A, Brito LA, Hassett KJ, et al. Preclinical and clinical demonstration of immunogenicity by mRNA vaccines against H10N8 and H7N9 influenza viruses. Mol Ther. 2017;25(6):1316-27. https://doi.org/10.1016/j.ymthe.2017.03.035.

296. Reichmuth AM, Oberli MA, Jaklenec A, Langer R, Blankschtein D. mRNA vaccine delivery using lipid nanoparticles. Ther Deliv. 2016;7(5):319-34. https://doi.org/10.4155/tde-2016-0006.

297. Pardi N, Hogan MJ, Porter FW, Weissman D. mRNA vaccines - a new era in vaccinology. Nat Rev Drug Discov. 2018;17(4):261-79. https://doi.org/10. 1038/nrd.2017.243

298. Schnekenburger M, Dicato M, Diederich MF. Anticancer potential of naturally occurring immunoepigenetic modulators: a promising avenue? Cancer. 2019;125(10):1612-28. https://doi.org/10.1002/cncr.32041.

299. Kowalski PS, Rudra A, Miao L, Anderson DG. Delivering the messenger: advances in technologies for therapeutic mRNA delivery. Mol Ther. 2019; 27(4):710-28. https://doi.org/10.1016/j.ymthe.2019.02.012.

300. Cai Q, Yang M, Liu D, Chen J, Shu D, Xia J, et al. Experimental treatment with Favipiravir for COVID-19: an open-label control study. Engineering (Beijing). 2020. https://doi.org/10.1016/j.eng.2020.03.007.

301. Ma Z, Li J, He F, Wilson A, Pitt B, Li S. Cationic lipids enhance siRNAmediated interferon response in mice. Biochem Biophys Res Commun. 2005;330(3):755-9. https://doi.org/10.1016/j.bbrc.2005.03.041.

302. Alberer M, Gnad-Vogt U, Hong HS, Mehr KT, Backert L, Finak G, et al. Safety and immunogenicity of a mRNA rabies vaccine in healthy adults: an open-label non-randomised, prospective, first-in-human phase 1 clinical trial. Lancet. 2017 ; 390(10101):1511-20. https://doi.org/10.1016/s0140-6736(17)31665-3.

303. Liang F, Lindgren G, Lin A, Thompson EA, Ols S, Röhss J, et al. Efficient targeting and activation of antigen-presenting cells In vivo after modified mRNA vaccine administration in rhesus macaques. Mol Ther. 2017;25(12): 2635-47. https://doi.org/10.1016/j.ymthe.2017.08.006.

304. Veljkovic V, Vergara-Alert J, Segalés J, Paessler S. Use of the informational spectrum methodology for rapid biological analysis of the novel coronavirus 2019-nCoV: prediction of potential receptor, natural reservoir, tropism and therapeutic/vaccine target. F1000Research. 2020;9:52. https:// doi.org/10.12688/f1000research.22149.3.

305. Yang ZY, Kong WP, Huang Y, Roberts A, Murphy BR, Subbarao K, et al. A DNA vaccine induces SARS coronavirus neutralization and protective immunity in mice. Nature. 2004;428(6982):561-4. https://doi.org/10.1038/ nature 02463.

306. Davis HL, Millan CL, Watkins SC. Immune-mediated destruction of transfected muscle fibers after direct gene transfer with antigen-expressing plasmid DNA. Gene Ther. 1997;4(3):181-8. https://doi.org/10.1038/sj.gt. 3300380.

307. Coombes BK, Mahony JB. Dendritic cell discoveries provide new insight into the cellular immunobiology of DNA vaccines. Immunol Lett. 2001;78(2):10311. https://doi.org/10.1016/s0165-2478(01)00242-5.

308. Suschak JJ, Williams JA, Schmaljohn CS. Advancements in DNA vaccine vectors, non-mechanical delivery methods, and molecular adjuvants to increase immunogenicity. Hum Vaccin Immunother. 2017;13(12):2837-48. https://doi.org/10.1080/21645515.2017.1330236.

309. Hobernik D, Bros M. DNA vaccines-how far from clinical use? Int J Mol Sci. 2018;19(11). https://doi.org/10.3390/ijms19113605.

310. Condit RC, Williamson AL, Sheets R, Seligman SJ, Monath TP, Excler JL, et al. Unique safety issues associated with virus-vectored vaccines: potential for and theoretical consequences of recombination with wild type virus strains. Vaccine. 2016;34(51):6610-6. https://doi.org/10.1016/j. vaccine.2016.04.060

311. Du L, He Y, Zhou Y, Liu S, Zheng BJ, Jiang S. The spike protein of SARSCoV--a target for vaccine and therapeutic development. Nat Rev Microbiol. 2009;7(3):226-36. https://doi.org/10.1038/nrmicro2090.
312. Zheng XW, Tao G, Zhang MW, Yang GN, Huang P. Drug interaction monitoring of lopinavir/ritonavir in COVID-19 patients with cancer. Zhonghua Nei Ke Za Zhi. 2020; 59(5):400-4. https://doi.org/10.3760/cma.j.cn112138-20200219-00097.

313. Agrawal B, Gupta N, Vedi S, et al. Heterologous immunity between adenoviruses and hepatitis $\mathrm{C}$ virus (HCV): recombinant adenovirus vaccine vectors containing antigens from unrelated pathogens induce cross-reactive immunity against HCV antigens. Cells. 2019;8(5):507. https:/doi.org/10.3390/cells8050507.

314. Crosby CM, Matchett WE, Anguiano-Zarate SS, et al. Replicating single-cycle adenovirus vectors generate amplified influenza vaccine responses. J Virol. 2017;91(2):e00720-16. https://doi.org/10.1128/JVl.00720-16.

315. Yamamoto Y, Nagasato M, Yoshida T, Aoki K. Recent advances in genetic modification of adenovirus vectors for cancer treatment. Cancer Sci. 2017; 108(5):831-7. https://doi.org/10.1111/cas.13228.

316. Kim Y, Kwon O, Paek JH, Park WY, Jin K, Hyun M, et al. Two distinct cases with COVID-19 in kidney transplant recipients. Am J Transplant. 2020;20(8): 2269-75. https://doi.org/10.1111/ajt.15947.

317. Zhu F, Li Y, Guan X, Hou L, Wang W, Li J, et al. Safety, tolerability, and immunogenicity of a recombinant adenovirus type-5 vectored COVD-19 vaccine: a dose-escalation, open-label, non-randomised, first-in-human trial. Lancet. 2020; 395(10240):1845-54. https:/doi.org/10.1016/S0140-6736(20)31208-3.

318. Tu YF, Chien CS, Yarmishyn AA, Lin YY, Luo YH, Lin YT, et al. A review of SARS-CoV-2 and the ongoing clinical trials. Int J Mol Sci. 2020;21(7). https:// doi.org/10.3390/ijms21072657.

319. Lewēn S, Zhou H, Hu HD, Cheng T, Markowitz D, Reisfeld RA, et al. A Legumainbased minigene vaccine targets the tumor stroma and suppresses breast cancer growth and angiogenesis. Cancer Immunol Immunother. 2008;57(4):507-15. https:// doi.org/10.1007/s00262-007-0389-x.

320. Stone BC, Kas A, Billman ZP, Fuller DH, Fuller Л, Shendure J, et al. Complex minigene library vaccination for discovery of pre-erythrocytic plasmodium $T$ cell antigens. PLoS One. 2016;11(4):e0153449. https://doi.org/10.1371/journal.pone. 0153449.

321. Pinchuk I, Starcher BC, Livingston B, Tvninnereim A, Wu S, Appella E, et al. A CD8+ T cell heptaepitope minigene vaccine induces protective immunity against chlamydia pneumoniae. J Immunol. 2005;174(9):5729-39. https:/doi.org/10.4049/jimmunol.174. 9.5729 .

322. Zhou H, Luo Y, Mizutani M, Mizutani N, Becker JC, Primus FJ, et al. A novel transgenic mouse model for immunological evaluation of carcinoembryonic antigen-based DNA minigene vaccines. J Clin Invest. 2004;113(12):1792-8. https:// doi.org/10.1172/jci21107.

323. Aurisicchio L, Fridman A, Bagchi A, Scarselli E, La Monica N, Ciliberto G. A novel minigene scaffold for therapeutic cancer vaccines. Oncoimmunology. 2014;3(1): e27529. https://doi.org/10.4161/onci.27529.

324. Pourseif MM, Moghaddam G, Naghili B, Saeedi N, Panizpour S, Nematollahi A, et al. A novel in silico minigene vaccine based on CD4(+) T-helper and B-cell epitopes of EG95 isolates for vaccination against cystic echinococcosis. Comput Biol Chem. 2018;72:150-63. https:/doi.org/10.1016/j.compbiolchem.2017.11.008.

325. Wu SC. Progress and concept for COVID-19 vaccine development. Biotechnol J. 2020;15(6):e2000147. https://doi.org/10.1002/biot.202000147.

326. Smith TRF, Patel A, Ramos S, Elwood D, Zhu X, Yan J, et al. Immunogenicity of a DNA vaccine candidate for COVD-19. Nat Commun. 2020;11(1):2601. https:/doi.org/ 10.1038/s41467-020-16505-0.

327. Cimolai N. Defining protective epitopes for COVID-19 vaccination models. J Med Virol. 2020. https://doi.org/10.1002/jmv.25876.

328. Herst CV, Burkholz S, Sidney J, Sette A, Harris PE, Massey S, et al. An effective CTL peptide vaccine for Ebola Zaire based on Survivors' CD8+ targeting of a particular nucleocapsid protein epitope with potential implications for COVID-19 vaccine design. Vaccine. 2020;38(28):4464-75. https://doi.org/10. 1016/j.vaccine.2020.04.034.

329. Wang L, Xu X, Ruan J, Lin S, Jiang J, Ye H. Quadruple therapy for asymptomatic COVD-19 infection patients. Expert Rev Anti-Infect Ther. 2020;18(7):617-24. https:// doi.org/10.1080/14787210.2020.1758066.

330. Lu S. Timely development of vaccines against SARS-CoV-2. Emerg Microbes Infect. 2020;9(1):542-4. https://doi.org/10.1080/22221751.2020.1737580.

331. Graham BS. Rapid COVID-19 vaccine development. Science (New York, NY). 2020;368(6494):945-6. https://doi.org/10.1126/science.abb8923.

332. Rubel AR, Chong PL, Abdullah MS, Asli R, Momin RN, Mani Bl, et al. Lipemic serum in patients with coronavirus disease 2019 (COVID-19) undergoing treatment. J Med Virol. 2020. https://doi.org/10.1002/jmv.25942.

333. Triggle $C R$, Bansal D, Farag E, Ding H, Sultan AA. COVID-19: learning from lessons to guide treatment and prevention interventions. mSphere. 2020;5(3). https:/doi.org/ 10.1128/mSphere.00317-20. 
334. Hotez PJ, Corry DB, Bottazzi ME. COVID-19 vaccine design: the Janus face of immune enhancement. Nat Rev Immunol. 2020;20(6):347-8. https:/doi.org/10.1038/ s41577-020-0323-4.

335. Beck BR, Shin B, Choi Y, Park S, Kang K. Predicting commercially available antiviral drugs that may act on the novel coronavirus (SARS-CoV-2) through a drug-target interaction deep learning model. Comput Struct Biotechnol J. 2020;18:784-90. https:/doi.org/10.1016/j.csbj.2020.03.025.

336. Hassan Ahmed O, Kafai Natasha M, Dmitriev Igor P, Fox Julie M, Smith Brittany K, Harvey lan B, et al. A single-dose intranasal ChAd vaccine protects upper and lower respiratory tracts against SARS-CoV-2. Cell. 2020;183(1):169-184.e13. https:/doi.org/ 10.1016/.cell.2020.08.026.

337. Robson B. Computers and viral diseases. Preliminary bioinformatics studies on the design of a synthetic vaccine and a preventative peptidomimetic antagonist against the SARS-CoV-2 (2019-nCoV, COVID-19) coronavirus. Comput Biol Med. 2020;119 103670. https://doi.org/10.1016/..compbiomed.2020.103670.

338. Poland GA. Tortoises, hares, and vaccines: a cautionary note for SARS-CoV-2 vaccine development. Vaccine. 2020;38(27):4219-20. https://doi.org/10.1016/j.vaccine.2020.04.073.

339. Rojas M, Rodríguez Y, Monsalve DM, Acosta-Ampudia Y, Camacho B, Gallo JE, et al. Convalescent plasma in Covid-19: possible mechanisms of action. Autoimmun Rev. 2020;19(7):102554. https:/doi.org/10.1016/.jautrev.2020.102554.

\section{Publisher's Note}

Springer Nature remains neutral with regard to jurisdictional claims in published maps and institutional affiliations. 